\title{
How to Place August 15 in South Korean History? The New Right, the "1948 Foundation" Historical View, and the 2008 Kŏn'gukchŏl Dispute
}

\author{
Patrick Vierthaler
}

\begin{abstract}
In Korea, August 15 marks both the liberation from colonialism (1945) and the promulgation of the South Korean state (1948). As a memorial day, 8.15 became to be narrated mostly as the day of liberation, while 1948 plays only a minor role. However, in the 2000s, the emergence of the New Right brought new debates on how to evaluate post-liberation history. A historical view proposing public memory on 8.15 centred on the "foundation" of South Korea emerged (kön'guk view). Combined with attempts to re-name 8.15 into a foundation day ${ }^{1}$ (kŏn'gukchŏl), an intense dispute between proponents and opponents of the re-narration was the result. This paper outlines the emergence of the New Right and traces the origins and politicisation of the kŏn'guk view and demonstrates how adopting the kŏn'guk narrative in state commemoration events led to a broad dispute in South Korean society. I trace this view's origin to 2003 and argue that it got politicised in early 2008 during the early Lee Myung-bak administration. The politicisation resulted in a dispute in politics, civil society, and newspapers, whose progress and characteristics I analyse in detail. As a result of the 2008 Kŏn'gukchŏl Dispute, the issue of how to narrate the events of 1948 became actively discussed in academic scholarship since 2009.
\end{abstract}

Keywords: Korea, New Right, August 15, historical revisionism, foundation, dispute, liberation, kwangbokchŏl, kŏn'gukchŏl

Vierthaler, Patrick. 2018. "How to Place August 15 in South SCin Korean History? The New Right, the '1948 Foundation' Historical View, and the 2008 Kŏn'gukchŏl Dispute." Vienna Journal of East Asian Studies, 10, pp. 137-174.

https://doi.org/10.2478/vjeas-2018-0006

\footnotetext{
${ }^{1}$ All translations from Korean and Japanese, if not stated otherwise, were done by the author. Also, emphases within citations are added by the author, if not stated otherwise.
} 


\section{Introduction}

August 15 (henceforth: 8.15) has a double-meaning in South Korean contemporary history. It marks both the liberation from Japanese colonial rule in 1945 and the promulgation of the Republic of Korea (henceforth: South Korea) in 1948. From an ethnic-nationalist perspective, 1945 marks the moment when the ancient nation of Korea was liberated from Japanese colonialism. The year 1948, with the establishment of the Southern and Northern governments, marks the political division of the Korean peninsula in two ideologically opposed modern nation-states. In the shadows of the emerging Cold War, South Korea, as part of the US centred UN world system, de jure constituted a liberal democracy. However, in reality a rigorous anticommunist system to justify autocratic rule was to become its raison d'être from the very moment of state-foundation onwards.

In historiography, a central issue is how to interpret the legacy of the events of 1945-1948 (the liberation period), and whether to narrate them as a continuity or a rift in Korean history. Division constitutes a national tragedy in ethnic history. Therefore, re-unification is a national goal in Korean contemporary historiography. However, with an ever-growing economic and social disparity between the North and South, unification is increasingly perceived as a burden rather than the only destination among younger generations of South Koreans (Campbell 2016). These tendencies are also reflected in the New Right's attempts to re-narrate South Korean history, as this paper will clarify below.

In public memory, 8.15 is called kwangbokchŏl 광복절/光復節, literally 'the day of the return of the light.' Since the mid-1950s, 8.15 is primarily associated with the liberation (haebang 해방/解放) from Japanese colonial rule in 1945. For example, 1995 therefore did not count as marking the "47th kwangbokchól" but the "50th kwangbokchŏl."

Table 1: Terminology used to refer to 8.15 in a (South) Korean context

\begin{tabular}{l|l|l} 
Romanisation & Han'gŭl (Hanja) & Translation \\
\hline haebang & 해방 (解放) & liberation \\
\hline tongnip & 독립 (独立) & independence \\
\hline kwangbok & 광복 (光復) & $\begin{array}{l}\text { "return of the light," a term used in Korean and } \\
\text { Chinese context; carries the connotation of re-gaining } \\
\text { independence }\end{array}$ \\
\hline $\begin{array}{l}\text { (nambuk) chóng- } \\
\text { bu surip }\end{array}$ & $\begin{array}{l}\text { (남북) 정부수립 } \\
\text { ((南北) 政府樹立) }\end{array}$ & $\begin{array}{l}\text { promulgation of the (Northern and Southern) gov- } \\
\text { ernment(s) in 1948 }\end{array}$ \\
\hline pundan & 분단 (分断) & separation / division \\
\hline kón'guk & 건국 (建國) & foundation (of the nation / state / nation-state)
\end{tabular}


In the Democratic People's Republic of Korea (DPRK, henceforth: North Korea), 8.15 is called kwangbokchŏl and serves as a memorial day to commemorate national liberation from Japanese colonial rule. Kwangbokchŏl is the only mutual holiday of the two present Korean states. Because the double-meaning of 8.15 is non-existent in a North Korean context, the foundation of the nation-state is separately celebrated on September 9, termed 'Day of the Establishment of the People's Government' (inmin chŏnggwŏn ch'anggŏnil 인민정권 창건일/人民政權 創建日). Therefore, kwangbok in a North Korean context has the unique meaning of "liberation" as opposed to the various ways 8.15 can be called in a South Korean context. ${ }^{2}$

In this paper, I focus on the New Right's attempts to change public memory regarding 8.15 and the debate that resulted out of it. This happened in two ways. First, New Right affiliated scholars proposed their views through newspaper columns, journal articles, and debates. Regarding 8.15, they proposed a narrative centred on the events and legacy of 1948, thus a memory focused on the establishment and achievements of the South Korean state, the so-called kŏn'guk sagwan 건국사관/建國史観 ('national foundation historical view,' henceforth: kŏn'guk view). Second, a number of lawmakers repeatedly attempted to re-name 8.15 from kwangbokchŏl to kŏn'gukchŏl 건국절/建國節, thereby aiming for a memorial day remembering history as interpreted by the kŏn'guk view.

First, after a brief overview of prior research, I will summarise the emergence of the New Right. In which socio-political context did it take place? What did the New Right stand for? How is the emergence of the New Right evaluated in South Korean academia? Second, I will outline how public memory and memorial days are created and how they are connected to historical writing. How was South Korean public memory created? Where does South Korea as a state draw its historical legitimacy from in the reality of political division?

\footnotetext{
${ }^{2}$ The historical meaning of kwangbok in a South Korean context was analysed by historian Sŏ Chung-sŏk (an opponent to the kŏn'guk view) as part of the number of academic publications that sprang from the 2008 Kŏn'gukchŏl Dispute. Sŏ pointed out the original meaning of kwangbok as incorporating "foundation" and "(re-gaining) independence," kwangbokchŏl therefore being a deliberate choice to commemorate both the liberation of 1945 and the proclamation of the government of 1948 (Sŏ 2009: 54-56; 62). Sŏ also points out that a shift in meaning has taken place since the 1960s, with kwangbok shifting to "liberation" (ibid.). This usage of kwangbok strictly meaning "liberation" is found in primary sources of the 2008 Kŏn'gukchŏl Dispute, e.g., in the draft bills to re-name 8.15 from 2007 and 2008, in Lee Myung-bak's commemoration speech on 8.15, or in Yi Yŏng-hun's column of July 2006. Later on, New Right scholars Yi Yŏng-hun (2011: 62-67) and Yang Tong-an (2016: 134-140) came to the same conclusions as Só. However, for them, the shift in meaning from "independence" = "foundation" to "liberation" does not represent a natural shift, but rather a "distortion of history" that "provided an opportunity for memory of the foundation to be forgotten" and therefore "needs to be corrected."
} 
Before I analyse the chronologic events, I sum up the kŏn'guk view's core argumentation regarding the events and legacy of the 1948 state formation as can be deducted from primary sources of the analysed period. The analysis itself attempts to answer three major research questions: First, I trace the origins and the emergence of the kŏn'guk view and the attempts to re-name 8.15, as well as how this historical view got politicised. Second, I show how the politicisation led to the 2008 Kŏn'gukchŏl Dispute. How did the dispute progress? When was its peak? Who participated in the dispute and how? How did it end? Third, by conducting a quantitative and qualitative analysis of newspaper reporting on the issue, I clarify what the fault lines of the 2008 Kŏn'gukchŏl Dispute were.

Regarding methodology, I use a historical discourse analysis. I approach the topic from the concept of "official memory" and "official history." How is official memory defined and how are such narratives challenged? Furthermore, presuming the South Korea of the 2000s to be a "well-established nation-state," I employ the concept of "banal nationalism" as a means for source criticism. For Billig, nationalism does not only constitute the core of the very creation of nation-states (cf. Anderson 1983; Gellner 1983) or the periphery of established nation-states (e.g., far-right nationalism), but is at the core of well-established nation-states. Billig terms this aspect of nationalism as "banal nationalism." Such nationalism is daily reproduced, e.g., in the form of weather forecasts or sports coverage. "Banal nationalism operates with prosaic, routine words, which take nations for granted, and which, in so doing, inhabit them" (Billig 1995: 93). Creating a space of "us" versus "them," banal nationalism unconsciously shapes identities.

In other words, nationalism is neither something historical nor negative, but something every one of us unconsciously experiences on a daily basis; "it becomes something surplus to everyday life" (ibid.: 42). In particular, newspaper editorials become a nationalised syntax of hegemony, employing a complex deixis of "here" and "now" (ibid.: 114-119). Thus, in the present study, newspaper editorials and columns become a primary source for analysing the argumentation and fault lines in the 2008 Kŏn'gukchŏl Dispute.

\section{Preceding Studies on the 2008 Kŏn'gukchŏl Dispute}

A serious problem for selection arises regarding existing literature on the 2008 Kŏn'gukchŏl Dispute: namely, objectivity. If a study on the topic is written with a clear "goal," such as legitimising or de-legitimising certain points of view, this research becomes a primary source, not a prior study. For the analysed topic, only one paper could be found that in some detail dealt with the chronology of the 2008 commemoration events and the attempts to change the meaning of 8.15 (Ha 2012). However, Ha rarely used any primary sources in his analysis and instead of analysing the 
origins of the kŏn'guk view, he focused on the political aspects of the 2008 kŏn'guk commemoration events.

Other papers focus on concrete contents of the kŏn'guk view, such as the constitution and its meaning, the way history is written, or the way history is narrated in the kŏn'guk view. Chi Su-gŏl (2016) states that one major obstacle for resolving this dispute is that the South Korean constitution allows for pluralistic interpretations. Chi argues that, more than anything, a dialogue between different schools of thought needs to take place to resolve the issue. Similarly, Yi Wan-bŏm (2009) points out that whether one reads kŏn'guk as the foundation of the "political (nation-) state" (1919, 1948) or the "ethnic nation" ("ancient"), or regarding the modern nation-state in the sense of ethnic history (1919) or international law (1948), one necessarily arrives at different conclusions. Ko Chi-hun (2008) traces the core of the dispute in whether to approach history from the point of the "elite" or the "mass" (minjung 민중/民衆). In this context, for the ruling elite, South Korea was a legitimate state, a bulwark of antiCommunism during the Cold War that successfully developed its economy and society. For the ruled mass, however, there was a sharp discrepancy between constitutional theory and lived experience: their reality was state violence and authoritarianism. For Ko, the New Right's version of history is a history from a macro perspective, blindly objectivising statistical data and putting them in a large, comparative perspective, thus ignoring the individual sufferings of the Korean people.

All in all, there are three shortcomings in the existing literature: First, there is not a single study on the emergence of the kŏn'guk view in conservative intellectual thought and how it became the core narrative of the 2008 commemoration events, neither in Korean nor in other languages. Second, there is no pre-existing analysis of the dispute that was a result of its adoption as the official narrative. Third, much of the published literature in Korean tends to be biased towards one view or the other.

\section{The Emergence of the New Right in the Early 2000s ${ }^{3}$}

Against the background of two progressive governments and historical reconciliation policies, the (self-proclaimed) South Korean New Right (henceforth: New Right)

\footnotetext{
${ }^{3}$ It must be noted that another major interest for the New Right - apart from how to evaluate and narrate (South) Korean contemporary history-is the question of Japanese colonialism and its legacy. Topics related to these trends include primarily economic and legal issues like the Colonial Modernity Theory, but also sex-slavery during WW2 (the so-called "comfort women") and collaboration. However, in order not to go beyond the scope of this paper, I discuss the New Right's historical interests focused on a post-1945 (i.e., contemporary) perspective only.
} 
emerged in the mid-2000s as a challenge, not only to the progressives, but also to intellectual thought on the "conventional" conservative 4 side.

For conservatives, who held power in South Korea since 1948, the election of Kim Dae-jung as president in 1997 marked a rift. However, because the conservative Hannara party 한나라당 (Grand National Party) still managed to hold a majority of seats in the National Assembly, many conservatives saw the victory of Kim Dae-jung as an interim situation. When in 2003 the progressive Roh Moo-hyun consecutively won the presidential election, this began to change. Conservatives tried to impeach Roh in his first year of government but failed. Following the failed impeachment, Roh's Uri Party (yŏllin uridang 열린우리당) won the National Assembly elections in April 2004, giving the progressives control of both the executive and legislative branches of government. For conservatives, this marked a moment of existential crisis (Pak 2012: 496-497): for the first time in their history, the conservatives were truly ousted from political power. Later on, the New Right began to refer to this period as the "ten lost years."

In the late 1990s and early 2000s, historical reconciliation policies regarding South Korean state violence and responsibility became the focus of state-sponsored historical research (cf. Suh 2010; Kim DC 2010). In 2005, the Truth and Reconciliation Commission in Korea was established, which is evaluated by Suh Jae-jung (2010: 511-513) as "the culmination of a long and heroic struggle to bring the state's violence to justice. [...] Questions of compensation, memorials, and legality began to eclipse, if not replace, those about the legitimacy, governmentality, and exceptionality of the state."

These policies are indirectly a product of over twenty years of Korean contemporary history (hyŏndaesa 현대사/現代史) as a profession, whose institutionalisation can be traced to the year 1980 (Em 2013: 152-155). ${ }^{5}$ For the first time, the period after 1945 could be studied thoroughly without an anti-Communist and a postcolonial tunnel vision. In its first years, the discipline was heavily influenced by Cold

\footnotetext{
${ }^{4}$ Contemporary South Korea's ideological poles are often termed as “conservative” (posu 보수/保 守) and "progressive" (chinbo 진보/進歩). For reasons of simplicity, I will stick to the use of these terms in this article.

${ }^{5}$ The publication of Haebang chŏnhusa'üi insik (Perceptions of Korean History Before and After Liberation; Song et al. 1979-1989, henceforth Insik) marks a critical rift in Korean historiography. The aim of Insik was to construct a contemporary history free of (anti-communist, Cold War) ideology (Em 2013: 152-154). However, as critics point out (Yu 1998), this on the other hand turned out to be a highly ethnic nationalist history. Furthermore, research institutes focusing on the modern/contemporary period, such as the Yŏksa Munje Yŏnguso 역사문제연구소/歴史問題研究 所 (founded 1986, journals Yŏksa Munje Yŏngu 역사문제연구/歴史問題研究 and Yŏksa Pip'yŏng 역사비평/歴史批評) were founded in the 1980s and form a centre of contemporary historical research in South Korea.
} 
War Revisionists ${ }^{6}$ like Bruce Cumings. ${ }^{7}$ As the renowned historian Yu Yŏng-ik 유영익 notes (1998: 9-13), Cumings brought an intellectual revolution to Korean historiography, with his methods becoming mainstream in the 1990s. At the same time, $\mathrm{Yu}$ criticises that this in turn led to an over-focusing on the liberation period. Furthermore, the strong influence by Cold War Revisionism in term led to a narrative of powerful binaries: "genuine nationalism" versus "mindless anti-Communism," with Rhee Syngman becoming the primary target of critique and a unificationoriented historiography as its main result (Em 2013: 152-153).

To date, there is no coherent analysis of the emergence and characteristics of the New Right in non-Korean scholarship. Among the existing literature, Chŏng Hae-gu 정해구 (2006: 216-228) provides the most detailed overview. ${ }^{8}$ According to Chŏng, the New Right can be divided into two separate branches: one, centred on the New Right Foundation (Nyurait'ŭ Chaedan 뉴라이트재단), and another on the National New Right Association (Nyurait'ŭ Chŏn'guk Yŏnhap 뉴라이트전국연합/뉴라이트 全國聯合).

The former was focusing on offering a new theoretical and ideological framework for South Korean conservatism. This branch was rather elitist in nature, highly academic, and ambivalent towards the conservative Hannara Party, at least up to Lee Myung-bak's win in 2007 (Chŏng 2006). The origins of this branch lie in the Liberalist Federation (Chayujuŭi Yŏndae 자유주의연대/自由主義連帶, founded in November 2004) and the Textbook Forum (Kyogwasŏ P'orŏm 교과서포럼/教科書포럼, founded in January 2005). Members of both organisations were widely overlapping (Pak 2012: 497). Many members of the LF and TF belonged to the 386 Generation (386 sedae 386 세 대/386 世代), ${ }^{9}$ among them a high number of former leftist democracy activists (Chŏng 2006: 221). Sin Chi-ho 신지호 or Hong Chin-p'yo 홍진표, two founders of the Liberalist Foundation, were originally members of pro-North Korean

\footnotetext{
${ }^{6}$ Cold War Revisionism is a school of US diplomatic history dating back to the late 1950s, with historians such as William A. Williams, Denna F. Fleming, and Gabriel Kolko. "Revisionism" in this context applies to the term the meaning of change (or a set of changes) that corrects or improves an orthodox or traditional doctrine. Cold War Revisionism differs from the term "revisionism" as it is widely used in Asian Studies, where it refers mostly to the far-right, nationalistic historical revisionism as propagated by Japanese textbook revisionists (e.g., Tsukuru Kai つくる会) of the 1990s.

${ }^{7}$ The publication and translation of Bruce Cumings' first volume of The Origins of the Korean War (Cumings 1981) sparked a huge interest in topics dealing with post-1945 events. Cumings analysed the liberation period as a diplomatic historian with a US perspective, but his thorough use of US, UN, and Korean primary sources in his argumentation received a favourable response in South Korea.

${ }^{8}$ Unfortunately, not a single website of a former New Right organisation, except for the journal Sidae Chŏngsin, is accessible to date (May 2018).

${ }^{9}$ This term is used to refer to the generation of South Koreans born in the 1960s that were politically active during their student days in the 1980s. Many members of the 386 Generation are said to be much more politically left-leaning than their parents.
} 
student movements in the 1980s (so-called chusap'a 주사파), but had themselves “converted” in the early 1990s (chŏnhyangja 전향자/転向者).

For Sin and Hong, the democratisation movement incorporated two central elements: (1) simple anti-authoritarianism and (2) the ideology of minjung, a Korean version of class-conscious ideology focused on the "ordinary people/mass" as opposed to the rulers/elite. ${ }^{10}$ For Sin Chi-ho, the latter represented "leftist," "communist" elements, found in the Roh administration (Chŏng 2006: 222). This anti-Roh, anti-North stance, criticising Roh and the progressives as "pro-North leftists" (chinbukchwap' $a$ 진북좌파/親北左派), became the dominant characteristic of the "New" Right. In October 2005, eight New Right affiliated organisations, among them the LF and the TF, merged to form the New Right Network (Nyurait' $\breve{u}$ Net'ŭwŏk'ŭ 뉴라이트 네트워크). In April 2006, the NRN merged into the newly founded New Right Foundation. The NRF had its own academic journal, Sidae Chŏngsin 時代精神 (Zeitgeist, published from 2006 to 2017).

The second branch, represented by the National New Right Association, was much bigger in terms of members and organisation (Chŏng 2006: 216-228). Unlike the NRF, the NNRA was close to the Hannara Party, with both later presidents Lee Myung-bak and Park Geun-hye serving as founding members. However, despite differences between the two branches of New Right on how to approach the "old right" and how to re-structure South Korean conservatism, both branches shared the following goals and values: Highly valuing market-oriented, (neo-)liberalism; the need of becoming an "advanced nation" (sŏnjinhwa 선진화/先進化); sharp critique of the Roh government as "leftist, pro North-Korean"; and a hard-line stance towards North Korea.

A major target of the New Right were the dominant historical narratives found in South Korean textbooks and the Roh government's reconciliation policies. As early as with the LF and the Textbook Forum, these views were called to promote a 'masochistic view of history' (chahak sagwan 자학사관/自虐史観). This term, first used in September 2004 by Tonga Ilbo, appears to have been imported literally from Japanese nationalist revisionism (Ha 2007: 185-187). The Textbook Forum mainly criticised school textbooks as being "biased" to promote "leftist" view, with its aim being to "properly re-evaluate" South Korean history and by doing so re-write (modern and contemporary) history textbooks. As Sin Chu-baek 신주백 (2006) analyses, "proper" in the context of the TF refers to a highly heroic, elite history focused on the nation-state, its rulers, and its (positive) achievements.

The significance of the New Right can be evaluated in three ways, depending on one's point of view. For political scientists and intellectual historians, the emergence of the New Right marks the "first re-orientation of conservative intellectual thought

\footnotetext{
${ }^{10}$ For the ideology of minjung and a socio-cultural history of the dissident movement, cf. Lee 2008.
} 
since the formation of the South Korean state" (Pak 2012: 496-497). The years following Roh's inauguration marked a point in South Korean history in which the return to power seemed almost impossible for the conservatives. In this climate, the conservatives had to re-invent themselves. As sources from the New Right's formative period reveal (Kim 2004; Im 2005), there were high expectations in parts of South Korean society for a new branch of Korean conservatism, free from vigorous anti-Communism and corruption scandals. However, as critics like Chŏng (2006), Sin (2006), and Ha (2007) point out, the adoption of a thoroughly anti-Roh Moo-hyun stance in combination with a fierce hardliner policy towards North Korea aroused suspicions if the New Right were actually "new" at all. In a way, the New Right came to resemble an "internal self-questioning" of Korean conservatism (Kim 2011: 29). The harsh stance towards North Korea in combination with neo-liberalist policies was in the Zeitgeist of the early 2000s, as most prominently seen in the Bush and Koizumi administrations.

Second, the New Right can be evaluated as the result of a generational conflict inside the 386 Generation. Although only ten out of seventy founding members of the LF were former leftist 386 Generation student activists (Chŏn 2005: 67), "converts" like Sin Chi-ho and Hong Chin-p'yo came to assume a central role in the New Right. In this context, criticising the Roh government by using the "pro-North Korea" framing becomes an internal struggle of the 386 Generation by "converted," "awakened" activist against "leftist," "pro-North Korean" former activists serving in the Roh administration (Kim 2017).

Third, for Korean contemporary history, the emergence of the New Right and their harsh critique on the historical reconciliation policies marks the "arrival of Japanese revisionism to South Korea" (Mun 2015: 250). With the adoption of revisionist terminology and state-centred narratives, the New Right's historical views are summed up by some scholars, such as Ha Chong-mun 하종문, as a "ruling classcentred political history [...] heavily influenced by Eurocentric views of civilisation and modernity" (Ha 2010: 33-43). At the same time, the New Right's academic publications (especially Pak et al. 2006) are evaluated by Henry Em as broadening the discourse on the liberation period (Em 2013: 155-158).

In existing studies on the New Right, the textbook issue is highly overrepresented (e.g., cf. Kim 2016), whereas there is almost no existing literature on other activities of the New Right that does not clearly "take sides." Therefore, rather than repeating how the dispute on history textbooks unfolded following the TF's foundation in 2005 , I decided to focus on the New Right's attempts to re-narrate a particular aspect of South Korean public memory. In doing so, I attempt to clarify how the New Right's views were adopted by the early Lee Myung-bak administration, and how a thitherto uncontested aspect of Korean history suddenly became the centre of a dispute, resulting in a large number of books on the topic to be published by scholars. 


\title{
South Korean Legitimacy, Official History, and Public Memory
}

The founding constitution of 1948 (Chehŏn hŏnbop 제헌헌법/政権憲法) was drafted between May and July of 1948, after the UN-observed elections in the southern parts of the peninsula on May 10. Division into two ideologically opposed nation-states was a reality at this point. Therefore, constitutionally founded historical legitimacy, both internal and external, was crucial in the moment of state institutionalisation.

In the preamble of the constitution, South Korea traces its legitimacy in two ways:

\begin{abstract}
We, the people of Korea, with a glorious tradition and history from time immemorial, following the indomitable spirit of independence, as manifested and proclaimed to the world in the establishment of the Republic of Korea in the course of the March 1 Independence Movement, now at this time re-establish a democratic independent state $[\ldots] .{ }^{11}$
\end{abstract}

This choice of words draws legitimacy from both an ethnic ("from time immemorial") as well as a post-colonial viewpoint (reference to the independence movement and the provisional government, as well as the choice of Republic of Korea, Taehan min'guk 대한민국/大韓民國, as the official name of the new nation-state), therefore claiming continuity and legitimacy in the face of imminent political division.

While not referring to any specific provisional government, the choice of the country name suggests a continuity with the Shanghai Provisional Government, therefore making South Korea the only legitimate successor of this government. As Sin Yong-ok 신용옥 shows (2016: 491), this choice of words was intentionally proposed by the later president Syngman Rhee to give the soon-to-be-founded state a broader historical legitimacy. The same can be said about choosing the date of the formal promulgation of statehood to 8.15 , the day that also marks liberation from colonial rule (Shin 2005: 57-58).

Following the institutional creation of a new nation-state, public memory as part of an official historical narrative is created, one such example being the "construction of memorial days" (Koseki 2007) to support legitimacy claims of newly-founded nation-states. Memorial days are a legally defined means inside a nation-state to provide citizens of this nation-state with a sense of identity and belonging (Nora 2002: 48-49). Essentially, a memorial day is made up of a date, a meaning (historical background), and a form (commemoration events) (Koseki 2007: 8-10). Therefore, it needs a story its contents "occupy a normative position in the nation-state" (ibid.). This story's evidence is traced both within "history" and "memory." History in this context is defined as "official history" written by academics; a "history that provides

11 “Taehan min'guk hŏnbop 대한민국헌법,” enacted July 17, 1948, The National Assembly Information System. Korean original: “유구한 역사와 전통에 빛나는 우리들 대한국민은 기미 삼일운동으로 대한민국을 건립하여 세계에 선포한 위대한 독립정신을 계승하여 이제 민주독립국가를 재건함에 있어서 [...].” 
the ruling class of a nation-state with its legitimacy and citizens with an identity, a sense of belonging" (Koseki 1999: 9-10). This necessarily creates a space of "us" versus "them" (ibid.). Memory constitutes an action that, conforming with the present, recalls certain events and provides them with a meaning (Koseki 2007: 1-4). Memory is both a process trying to recognise the past and a way of understanding it. However, there is no such thing as an absolute truth; rather, it is the norm that various interpretations of the same historical events coexist. In this context, the meaning of memorial days is subject to continuous interpretational change, an "endless cycle of remembering and forgetting" (Koseki 1999: 10), but also a repetitive struggle for hegemony over narrating official history.

In a South Korean context, the creation of public memory in the form of memorial days was carried out in 1949. Four memorial days (kukkyŏngil 국경일/国慶日) were enacted by law in October: March 1 (Samilchŏl 삼일절/三一節, March 1 Movement); July 17 (chehŏnjŏl 제헌절/政憲節, day of the enactment of the founding constitution); August 15 (kwangbokchŏl, 'day of the return of the light'); and October 3 (kaech'ǒnjŏl 개천절/開天節, day of the mythical founding of Korea by Tan'gun 단군/檀君). ${ }^{12}$ Out of these four, three can be connected to ethnic nationalism (March 1, August 15, October 3), three with the modern nation-state (March 1, July 17, August 15), and two with colonialism (March 1, August 15). Among the above, only 8.15 carries a double-meaning in the sense that it refers to two autonomous incidents in Korean history.

Along with the establishment of the South Korean state and the creation of a public memory, a strict anti-Communist system, de facto out-ruling the constitution, was formalised. Historian Pak Ch'an-p'yo 박찬표 (1997) defines this as the "1948 System." In December 1948, the National Security Law (NSL, kukka poanborp 국가보안법/国家保安法) was enacted. Under the name of "national security" and "safety," the NSL provided the Syngman Rhee government with a powerful legal foundation to purge political opponents. In 1949 alone, around 110,000 people were arrested based on the NSL. Furthermore, the law served as a basis to dissolve the committee founded in September 1948 that had the task to purge pro-Japanese collaborators (ch'inilp' $a$ 친일파/親日派). Instead of overcoming the past, many former pro-Japanese collaborators became important parts of the South Korean bureaucracy, police, and military (cf. Chung 2002). The issue of collaboration is haunting South Korean society to this day and the attempt to resolve the issue during the Roh government is one major reason for the rise of the New Right.

To conclude, South Korean legitimacy claims are overshadowed by not only the Cold War division of the Korean peninsula, but also by postcolonial aspects. The gap

12 “Kukkyŏngil'e kwanhan pŏmnyul 국경일에관한법률," law no. 53, enacted October 1, 1949, National Law Information Centre. 
between constitutional liberal democracy and the 1948 System and how to interpret it constitutes a deep rift between left and right up to this day.

\section{The kŏn'guk View: A Definition}

What precisely is the kŏn'guk view? For this paper, I first attempt a definition by tracing how the kŏn'guk view is argued in primary sources of the 2008 Kŏn'gukchŏl Dispute. The most fruitful source is a booklet on sixty years of South Korean history, edited and distributed by the Ministry of Culture, Sports, and Tourism (Munhwa Ch'eyuk Kwan'gwangbu 문화체육관광부/文化體育観光部, henceforth: MCST) to schools, military facilities, and other public institutions in October 2008 (Pak et al. 2008). Among its authors are the New Right affiliated historian Kang Kyu-hyŏng 강규형 and the political scientists Kim Yŏng-ho 김영호 and Kim Ir-yŏng 김일영.

Divided into six chapters, the booklet narrates South Korean history as a gradual success story. After an overview chapter summarising the later chapters (Ch. 1), the booklet's narration progresses from the "period of foundation" (as opposed to "liberation period," Ch. 2), to the decades of industrialisation and economic growth (Ch. 3), democratisation (Ch. 4), cultural achievements (Ch. 5), and closing with describing Lee Myung-bak's goal of "advancement" (Ch. 6). In Chapters 1 and 2, the reason for a kŏn'guk-centred narrative are explained in detail, as are definitions of what kŏn'guk means in relationship to liberation.

Overall, the kŏn'guk view is narrated in two key issues. The first problem is the definition of the term itself. The liberation of 1945 and the establishment of the South Korean state in 1945 are used in a metaphor of pregnancy: just as a birthday is not the day the mother became pregnant, but the day of birth, so should the legal formation of a state (1948), rather than the first steps (1919/1945) be remembered as its foundation day (Pak et al. 2008: 35-36). Also, agricultural metaphors of the season's first rain, tanbi 단비/甘雨 (1945), and the autumn harvest, ch'usu 추수/秋収 (1948), are used to clarify the relationship between liberation and foundation (ibid.).

More precisely, the term kŏn'guk is defined as:

Kŏn'guk literally connotes creating a state/nation [nara 나라]. Creating a state means to bestow a new political and economic order on people who live in a specific area. In our ethnic history, even before the establishment of South Korea there was a high number of dynastic nation-states. However, the political system of South Korea is fundamentally different from those earlier dynastic nation-states. Through the foundation of South Korea in 1948, our ethnicity for the first time in history was to live in a state in which liberalism and market economy were the fundamental principles and in which the freedom, equality, property rights and human rights were 
protected. [...] the ideological and institutional groundwork was arranged (Pak et al. 2008: $52) .{ }^{13}$

South Korea is a state created through free elections based on the founding constitution which we ourselves drafted. Since foundation, we have experienced a high number of autocratic governments and political hardships due to ideological polarities. However, we never abandoned the principles of liberalism and the market economy system (ibid.: 76$){ }^{14}$

Bestowing a new political and economic order in the forms of the introduction of liberal constitutionalism and a market economy system were central arguments of the New Right.

In the kon' 'guk view's argumentation, the adoption of these principles should be labelled as a "revolutionary event" that gave birth to a republican state system (Pak et al. 2008: 52), therefore resulting in the birth of modern citizens and a "republican, patriotic identity" (ibid.: 62). These decisions lay the foundation for the economic and democratic "history of success" that is narrated in the following chapters and that was also repeated by Lee Myung-bak in his commemoration speech on August 15, 2008.

The second key issue is how to elaborate the legacy of 1948; namely, whether and how much of the period's political decisions could be and were made autonomously. The kon'guk view admits that "it is a truth that decisions could not be made autonomously" (Pak et al. 2008: 38). However, the activities of Syngman Rhee, especially his policies of arguing for the establishment of a separate southern government as early as in June 1946, exemplify "overcoming internal political confusion and external difficulties, [as a result] miraculously giving birth to South Korea" (ibid.: 56). Rhee's activities, in the kŏn'guk view, mark "decisions after careful considerations" (ibid.: 65).

For proponents of these views, high voter turnout in the May 1948 elections is proof of the legitimacy of the new state, despite the North as well as Kim Ku and Kim Kyu-sik boycotting the elections (Pak et al. 2008: 59). The formation of a Southern state as it happened is described as the result of careful consideration, a natural event. These views, as will be analysed further down, are one major reason that led to a dispute on how to deal with the legacy of 1948 in the 2008 Kŏn'gukchŏl Dispute.

\footnotetext{
${ }^{13}$ Korean original: "건국(建國)은 문자 그대로 나라를 세운다는 뜻이다. 나라를 세운다는 것은 특정 지역에 사는 사람들에게 새로은 정치·겅제 질서를 부여한다는 것을 의미한다. 대한민국 건국 이전에도 우리 민족사에는 수많은 왕조국가가 세워진 사례가 있다. 그러나 대한민국의 국가 체제 성격은 이전의 어떤 왕조국가와도 본질적으로 다르다. 1948 년 대한민국 건국을 통해 우리 민족은 역사상 최초로 자유민주주의와 시장겅제를 기본원리로 하는 국가, 자유 - 평등 - 재잔권 - 인권이 보장된 국가에서 살게 되었다. ( $\cdots)$ 이념적 • 제도적 기반이 마련된 것이다."

${ }^{14}$ Korean original: "대한민국은 우리 스스로 만든 제헌헌법에 따라 자유로운 선거를 통해 건설한 국가이다. 건국 이후 우리는 수많은 우여곡절을 겪었지만, 자유민주주의와 시장경제체제라는 원칙에서 벗어난 적은 없었다."
} 
Furthermore, not only is state violence during the liberation period (nor the Kwangju uprising) not mentioned in the MCST booklet, but also the complex domestic political situation of the liberation period (cf. Cumings 1981; 1990) is largely undealt with, as are the independence movement(s) South Korea claims its legitimacy from.

In course of the dispute resulting from the emergence of the kŏn'guk view, specialised liberation period historians such as Sŏ Chung-sŏk 서중석, Han Hong-gu 한홍구 (Han 2009), Han Si-jun 한시준 (Han 2017), Pak Ch'an-p'yo (Pak 2008), or Kim T'ong-chun 김동춘 (Kim TC 2015) pointed out the various weak points of the kon'guk view's argumentation, such as the discrepancy between the de jure state system and the events that actually took place. The New Right's focusing on the introduction of liberalism and market economy as state principles also gets heavily criticised by scholars, since neither of the two terms can be found in the founding constitution, but were only introduced during the Yusin 유신/維新 Constitution (e.g., Chŏng 2017: 72-73).

However, instead of analysing the argumentation between proponents and opponents of the kŏn'guk view in scholarly publications, this paper focuses on how the kŏn'guk view emerged in broader society, how it got politicised during the early Lee Myung-bak administration, and how the issue of re-narrating 8.15 turned into a dispute involving media, politics, civil society, and scholars.

\section{The Emergence of the kŏn'guk View (2003-2007)}

The first attempts to re-write public memory on 8.15 can be traced back to 2003, when Roh Moo-hyun served his first year of office as President, although the term kŏn'guk itself was already used earlier by some conservative scholars when referring to the events of 1948 (e.g., Yang 2001). In a rally targeting Roh's historical reconciliation and North Korea policies, conservative groups used the term "55 years kŏn'guk." ${ }^{15}$ Furthermore, on June 4, a draft bill to change the name of 8.15 from kwangbokchŏl to kŏn'gukchŏl was submitted in the National Assembly. ${ }^{16}$ Represented by Kim Yong-ha and filed by thirteen lawmakers from the oppositional Hannara Party, the draft bill argued that re-naming 8.15 would "foster unity of the people," enable a "spirit of national development," and help overcoming a "revenge attitude and victim awareness towards Japan," therefore transforming 8.15 into a "futureorientated" memorial day. Kim furthermore elaborated his views in an article pub-

15 "Kwangbokchŏl siwi taegyŏl ... kwangbok chikhu pangbul 광복절 시위대결… 광복직후 방불," Chosun ilbo, August 16, 2003.

16 “Kukkyŏngir'e kwanhan pŏmnyul chunggaejŏng pŏmnyuran 國慶日에關한法律 中改正法律案," bill no. 2350, 발의연월일 2003.6.4, The National Assembly Information System. 
lished in the National Assembly Review Kukhoebo 國会報. ${ }^{17}$ As kwangbokchŏl, 8.15 presented "an anomaly, [a memorial day] full of dependency on the US and antiJapanese sentiments." So far, 8.15 was the only kukkyŏngil where "joy" was not the focus of commemorations. Therefore, re-naming 8.15 would bring a transformation of 8.15 into a "day of joy." However, the draft bill was abandoned without further examination in a parliamentary committee. Both the 2003 rally and draft bill went largely unnoticed in society - they were not reported in any major media.

This changed in the years 2006 and 2007. First, columns and editorials arguing for the need to re-name and re-narrate 8.15 began to appear in the conservative newspapers. On July 31, 2006, Tonga ilbo featured a column by Yi Yŏng-hun 이영훈 18 where he proposed to create a "foundation day" (kŏn'gukchŏl). ${ }^{19} \mathrm{Yi}$ argues that the South Korean youth lack proper knowledge regarding when South Korea was founded. Furthermore, he criticises the focus of the annual kwangbokchŏl commemorations on 1945, which Yi claims were resulting in a "lack of knowledge" and "negative sentiments." For Yi, a "unifying national memory" must be created, and re-naming 8.15 would create a day of celebration.

On August 14, Yi's views were reported in Chosun ilbo, ${ }^{20}$ as well as a poll on the topic of South Korean foundation (kŏn'guk). ${ }^{21}$ According to the poll, 67.1 per cent of respondents did not know when South Korea was founded. Furthermore, 87.6 per cent connected 8.15 with the liberation from colonial rule. However, when questioned whether 8.15 should be re-named to commemorate the foundation of South Korea, 78.4 per cent of the respondents were also in favour. The results of this poll were used not only in editorials by Chosun ilbo on August 15, 2006 and 2007, ${ }^{22}$ but also subsequently by assemblymen (third draft bill, July 2008) and New Right affiliated scholars when arguing for the need of 8.15 (e.g., Kim YH et al. 2008: 79).

In September 2007, a second draft bill to re-name 8.15 was submitted in the National Assembly. Proposed by Chŏng Kap-yun (Hannara Party) and nine other law-

\footnotetext{
17 “Taehan min'guk, kŏn'gukchŏr'i piryohada 대한민국, 건국절이 필요하다,” Kukhoebo 國会報 442, pp. 38-40.

${ }^{18} \mathrm{Yi}$ Yŏng-hun is a key member of the New Right. Originally an economic historian with expertise on the capitalist system of the late Chosŏn period, he became increasingly involved in New Right matters. His history of South Korea, aimed at a general audience (Yi 2007), for example, is one of the most well-known publications of the New Right. In it, Yi argues that the development of South Korea was only possible due to modernisation during the colonial period in infrastructure, the legal system, and education.

19 “Uri'do kŏn'gukchŏr'ŭl mandŭlja 우리도 건국절을 만들자," Tonga ilbo, July 31, 2006.

20 “" 48-nyŏn 8-wŏl 15-il, taehan min'guk'ǔi sŏnt'aeg'ŭn chŏngdang haetta '48 년 8 월 15 일, 대한민국의 선택은 정당했다'," Chosun ilbo, August 14, 2006.

21 ““Kŏn'gug'ŭi 8.15'rŭl' asinayo ‘建國의 8.15'를 아시나요, ” Chosun ilbo, August 14, 2006.

22 "(Sasŏl) 8.15'e saengak hanŭn taehan min'gug'ŭi ŭimi (사설) 8.15 에 생각하는 대한민국의 의미”, Chosun ilbo, August 15, 2006; "(사설) 대한민국 건국 원훈들의 선택은 옳고 정당했다”, Chosun ilbo, August 15, 2007.
} 
makers, the contents were almost identical with the first one from $2003 .{ }^{23}$ Unlike the first one, the second draft made it into a parliamentary committee, but was dismissed eventually as "lacking support from broader society." 24

In the second half of 2007, the kŏn'guk view also emerged as an academic subject and a goal of future state commemoration events. In August, the New Right Foundation hosted a Symposium Commemorating 60 Years of Foundation (Kŏn'guk 60nyŏn Kinyŏm Haksul Hoeŭi 건국 60 년 기념학술회의/建國 60 年記念學術会議), funded by Chosun ilbo. The proceedings were later to be published as one of the first books arguing for a re-narration of South Korean contemporary history under the kŏn'guk view (Kim YH et al. 2008).

In November, the (civil) Preparation Committee for Commemorative Events of the 60th Anniversary of the Foundation (Kŏn'guk 60-nyŏn Kinyŏm Saŏp Chunbi Wiwŏnhoe 건국 60 년 기념사업위원회/建國 60 年記念事業委員会) was established. The aim of this committee was "to create a space of national celebration, in which the significance of the South Korean foundation is judged, and where the achievements of the people having contributed to it are [adequately] praised." 25 The committee argued that South Korean history needs to be celebrated as a "history of success," as opposed to the alleged "negative" view of history taken by the Roh government. ${ }^{26}$ A central member of this committee, who later played a key role in propagating the kŏn'guk view, was Yi In-ho 이인호, a scholar of Russian history and former diplomat.

In December, Lee Myung-bak of the Hannara Party won the presidential election by a landslide. At this stage, the kŏn'guk view still was limited to conservative circles within the Hannara Party, conservative dailies, and a number of New Right scholars. However, this was about to change once Lee Myung-bak took office in February 2008, bringing an end to ten progressive years of the Kim Dae-jung and Roh Moohyun. Whereas the "corrective" as proposed by the committee founded in November was highly anticipated by Chosun ilbo, a sharp opponent of Roh's reconciliation

23 "Kukkyŏngir'e kwanhan pŏmnyul ilbu kaejŏng pŏmnyuran 국경일에 관한 법률 일부개정법률안," 의안번호 7486, 발의연월일 September 27, 2007, The National Assembly Information System.

24 “Kukkyŏngir'e kwanhan pŏmnyul ilbu kaejŏng pŏmnyuran (Chŏng Kap-yun ŭiwŏn taep'yo parŭi) kŏmt'o pogosŏ 국경일에 관한 법률 일부개정법률안【정갑윤의원 대표발의】검토보고서," 행정자치위원회수석전문위원 (November 2007), The National Assembly Information System.

25 “2008-nyŏn kŏn'guk 60-chunyŏn kinyŏm saŏp pon'gyŏk chunbi nasŏ 2008 년 건국 60 주년 기념사업 본격 준비 나서," DailyNK, November 20, 2007.

26 “8-wŏl 15-il ŭn 'sŏn'gong'ŭi yŏksa' kyŏngch'ugil 8 월 15 일은 '성공의 역사' 경축일," Chosun ilbo, November 21, 2007. 
policies, ${ }^{27}$ the progressive newspaper Hankyoreh predicted a dispute to arise in 2008 regarding the status of 8.15 in public memory as one of many fault lines. ${ }^{28}$

\section{The Politicisation of the kŏn'guk View: The Kŏn'guk Committee and State Commemorations}

In the first months of Lee Myung-bak's term, the influence of the New Right on the state's historical narrative strengthened significantly. The kŏn'guk view got politicised - it became the official narrative of the 2008 commemoration events. On April 9, the Hannara Party celebrated the victory in the National Assembly elections, giving the conservatives power in both the executive and legislative branches of government.

The Committee for Commemorative Events of the 60th Anniversary of the Foundation of South Korea (Taehan Min'guk Kŏn'guk 60-nyŏn Kinyŏm Saŏp Wiwŏnhoe 대한민국건국 60 년기념 사업위원회/大韓民國建國 60 年記念事業委員会; henceforth: Kŏn'guk Committee) was established by Presidential Order No. $214 .^{29}$ It was placed directly under the office of the prime minister with the following aim:

Seeing the 60th anniversary of foundation of South Korea in 2008, the [Kŏn'guk Committee] is established under the prime minister's office to: Elaborate on the successful history of protecting one's country, industrialisation and democratisation; providing a vision to construct an advanced first-class nation; to efficiently hold, fund, create, coordinate and carry out various commemorative events. ${ }^{30}$

The Kŏn'guk Committee consisted of seventy-five [after revision: ninety-five] members, of whom fifteen [after revision: thirty-five] were to come from politics and sixty from civil society ( $\$ 4)$. The prime minister along with one civil member co-headed the committee, while any necessary funds for carrying out its duties were to be provided by the state $(\$ 13,16)$. According to a report in Hankyoreh 21, the Kŏn'guk

27 “(Siron) Kŏn'guk 60-chunyŏn kinyŏm saŏb’ŭn hyŏndaesa tasi ssŭgi putŏ [시론] 건국 60 주년 기념사업은 현 대사 다시 쓰기부터," Chosun ilbo, November 23, 2007.

28 “"Tandok chŏngbu' sŏnt'aek orassŭm'ŭn onŭlnal kukka wisang'i chŭngmyŏng '단독정부' 선 택 옳았음은 오늘날 국가 위상이 증명," Hankyoreh, December 31, 2007.

${ }^{29}$ The Presidential Order No. 214 was revised on August 14, 2008 with a change in member size: “Taet'ongnyŏng hunryŏng che 225-ho 대통령훈령 제 225 호," Kwanbo 관보 no. 16814, National Archives of Korea.

30 “Taet'ongnyŏng hunryŏng che 214-ho 대통령훈령 제 214 호," Kwanbo 관보 no. 16731, National Archives of Korea. Korean original: “대한민국 건국 60 년이 되는 2008 년을 맞아 건국이후 호국, 산업화, 민주화를 달성한 역사를 평가하고, 선진일류국가 건설을 위한 비전의 제시, 각종 행사의 개최 및 지원, 종합계획의 수립·조정·시행 등의 업무를 효율적으로 추진하기 위하여 국무총리소속하에 대한민국건국 60 년 기념사업위원회를 둔다.” 
Committee received funds of roughly twenty-eight billion Won in its roughly eight months of existence. ${ }^{31}$

Among the political members were the prime minister, heads of state ministries, and local governors. Civil members were to be "a person who is trusted by the citizens and rich in knowledge and experience" (§4). This included a list of people with such various backgrounds, of whom only Yi In-ho and Chŏng Ok-ja 정옥자 were historians. Among them, only Chŏng was a specialist in the field of Korean history (Chosŏn Period, not contemporary history).

The Kŏn'guk Committee formally started its activities on May 22, with a reception at the Blue House. The logo used in the official state events was unveiled (fig. 1); it consisted of two elements: a large " 60 " to refer to the sixtieth anniversary of South Korea, and the caption "Republic of Korea: Grand citizens, miraculous history."

Figure 3: The logo used in South Korean state commemoration events of 2008.

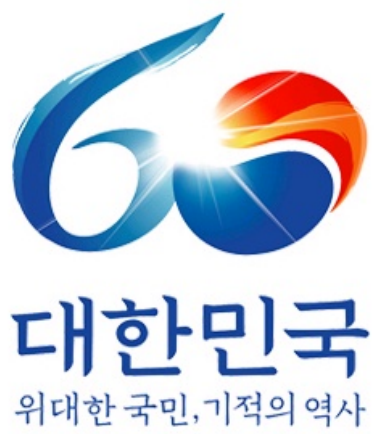

Source: Chŏngwadae.

Besides organising and carrying out state commemoration events, a further goal of the Kŏn'guk Committee was "to create [a favourable] public opinion by hosting seminars or debates" (§15). For example, the committee hosted a sixty-day lecture on sixty years of Korean history during the summer of $2008 .^{32}$ Also, following a symposium held in August 2008, Taehanmin'guk kŏn'guk 60-nyŏn'üi chaeinsik [A reinterpretation of 60 years since the foundation of South Korea] (Yi IH et al. 2009), a collection of academic articles was published, edited by Yi In-ho.

On July 11, Lee Myung-bak clarified his views on the need for a "positive history." In a festive address to the newly elected parliament, Lee declared "the inclusion

\footnotetext{
31 “Hŏnbop paggugo 'kŏn'guk' hasira 헌법 바꾸고 '건국'하시라,” Hankyoreh 21, 723.

32 “Onŭl put'o 60-il tongan kŏn'guk 60-chunyŏn kungmin taekangchwa 오늘부터 60 일동안 건국 60 주년 국민대강좌," KBS News, August 14, 2008.
} 
[of South Korea] into advanced nations" (sŏnjinhwa) and the goal to become a "firstclass global nation" as objectives of his presidency. ${ }^{33}$ In order to achieve them, a "positive and growth-oriented view of history" was indispensable "to produce development and national unity." With Lee as the former CEO of Hyundai, it comes as no surprise that he approached history from the viewpoint of "development" and "growth." These views largely converge with the historical views proclaimed by New Right affiliated scholars, such as An Pyŏng-jik 안병직 and Yi Yŏng-hun (cf. An and Yi 2007). Thus, at this stage, the historical views of Lee Myung-bak were closely intertwined with those of the New Right.

It is here that I trace the politicisation of the kŏn'guk view-in other words how the kŏn'guk view emerged as the official narrative of the state. The term kŏn'guk came to be used instead of kwangbok, (nambuk) chŏngbu surip (남북) 정부수립/(南 北)政府樹立, and pundan 분단/分断 when referring to the events of 1948 in official state documents of 2008 .

At the same time, on July 3, Chŏng Kap-yun 정갑윤 of the Hannara Party filed another, third draft bill to re-name kwangbokchŏl in the National Assembly. ${ }^{34}$ This bill, filed by thirteen members of the Hannara Party, was the igniting spark that resulted in the 2008 Kŏn'gukchŏl Dispute. The dispute is unimaginable without the politicisation of the kŏn'guk view and the repeated attempts to re-name 8.15. While the creation of the Kŏn'guk Committee, or the individual actions of a number of lawmakers alone, do not necessarily symbolise a rewriting of public memory, the combined events of the first half of 2008 do so. Therefore, I quote the entire third draft bill before analysing how the 2008 Kŏn'gukchŏl Dispute unfolded:

8.15 is both kwangbokchŏl, the day when the liberation from Japanese colonial rule in 1945 is commemorated, and the day when South Korea in 1948 was promulgated for the first time as an independent, modern, constitutional nation-state based on liberalism and market economy.

However, the annual commemorative events limit the meaning of 8.15 to kwangbokchŏl alone, the meaning of the South Korean foundation [kŏn'guk] gets omitted. The foundation ideology and spirit get neglected and according to one opinion poll [14 August 2006, Chosun ilbo, see above] around 70 per cent of South Koreans lack knowledge on the period when South Korea was founded, with the meaning of this foundation being in the process of being forgotten.

It is regrettable that among some parts [of society], the foundation of South Korea is being viewed as a forced and distressed proclamation of a half-nation.

Furthermore, because the liberation [kwangbok] of 1945 was not by ourselves and incomplete and the result was the atrocity of the birth of a divided nation, in a global age, the view [to commemorate 8.15 in this way] creates an emotional antipathy and an obstacle for a national spirit and policy aims.

33 "Che-18 kukhoe kaewŏn yŏnsŏl 제 18 국회 개원 연설," Presidential Speech, July 11, 2008, National Archives of Korea.

34 “Kukkyŏngir'e kwanhan pŏmnyul ilbu kaejŏng pŏmnyuran 국경일에 관한 법률 일부개정법률안," bill no. 132, July 3, 2008, The National Assembly Information System. 
Among the five national holidays, with 1 March and August 15 there are two holidays that concern Japan.

Therefore, 8.15 should be commemorated as not kwangbokchŏl but kŏn'gukchŏl. Doing so will recover liberalism as a founding ideology, which became the source of industrialisation and democratisation in only half a century. Also, it will strengthen the foundation spirit [kŏn'guk chóngsin], protect the legitimacy of South Korea, naturally establish a liberal democratic order in accordance with the constitution in the minds of the people and provides a mind to both aim for a future-oriented, free and prosperous South Korea, and create national unity and development. ${ }^{35}$

Unlike the two previous draft bills (2003 and 2007), this one marks the origins of what I name the "2008 Kŏn'gukchŏl Dispute."36 The draft bill was largely unnoticed in the first few days following its filing. However, with the Kŏn'guk Committee preparing a commemoration event on 8.15 focused largely on 1948, the bill got noticed by the media in late July. On July 20, the progressive newspaper Hankyoreh published its first editorial on the issue. It strongly criticised the aim to introduce a kŏn' 'gukchŏl as a "distortion of history," a "neglect of the independence movement's history," and a "disregard for historical views held by Syngman Rhee in 1948 himself." ${ }^{37}$ Following this, the number of articles dealing with kŏn'guk and kŏn'gukchŏl rose sharply in all major newspapers on both sides. The dispute peaked in the days

35 "Kukkyŏngir'e kwanhan pŏmnyul ilbu kaejŏng pŏmnyuran 국경일에 관한 법률 일부개정법률안," bill no. 132, July 3, 2008, The National Assembly Information System. Korean original: "8 월 15 일은 일본제국주의의 식민지배로부터 1945 년에 해방된 사실을 기념하는 광복절인 동시에 자유민주주의와 시장겅제의 가치에 접목시킨 독립된 근대입헌국가로서 1948 년에 '대한민국 정부'가 최초로 수립된 날이기도 함. 그러나 해마다 반복되는 8 월 15 일 기념식은 광복절의 의미에만 국한되어 있고 '대한민국 건국'의 의미는 축소되어 건국이념과 정신이 등한시 되고 있으며, 한 여론조사 결과에서 보듯이 $70 \%$ 에 가까운 국민이 대한민국 건국 시기에 대해서 잘 모르고 있는 등 그 역사적 중요성이 점점 잊혀져 가고 있음. 특히 일부에 의해 '대한민국 건국'을 해방 후 민족의 통일 염원에도불구하고 강행된 '반쪽자리 정부수립'이라는 불행한 사건으로 치부되고 있는 실정임. 그리고 1945 년 광복은 자력에 의한 광복이 아니라 불완전한 것으로 근대국가 건설에 분단국가라는 비극성을 낳았으며, 자칫 국제화시대에 반감적 감정을 가질 수 있는 상황을 초래하여 국가정신 및 정책지향에 걸림돌이 될 수 있음. 한편, 현행법에서 규정하고 있는 5 대 국경일 가운데 광복절과 3.1 절등 두개가 일본과 관련이 있는 날인 점도 고려해볼 측면임. 따라서 8 월 15 일은 광복절이 아닌 '건국일'로 기념하여 반세기만에 산업화와 민주화를 이룩하는데 근원이 된 자유민주 건국이념을 새롭게 가다듬고 건국정신을 드높여 대한민국 정체성과 정통성을 수호하고, 헌법정신에 맞는 자유민주적 기본질서를 자연스럽게 국민의식 속에 자리 잡게 함으로써 자유와 번영이 넘치는 미래지향적인 대한민국을 추구함과 동시에 국민의식통합과 국가발전의 의식을 고취시키고자하려는 것임."

${ }^{36}$ In Japanese, I use the term "First kŏn'gukchŏl Dispute” (dai-ichiji kenkokusetsu ronsō 第一次建 国節論争) as opposed to a “second” (ongoing) kŏn'gukchŏl dispute (Vierthaler 2018).

37 "(Sasŏl) Kinyŏmil do taet'ongnyŏng mŏttaero pakkuna (사설) 기념일도 대통령 멋대로 바꾸나”, Hankyoreh, July 20, 2008. 
prior to the commemoration events of 8.15 , involving politicians, journalists, civil societies, and scholars. ${ }^{38}$

The intense debate taking place in August led Chŏng Kap-yun to withdraw the draft bill and issue a public apology on September $12 .{ }^{39}$ Re-naming 8.15 ultimately failed, but the question on how to narrate the South Korean state's roots was just about to start in the summer of 2008.

\section{The 2008 Kŏn'gukchŏl Dispute}

The analysis of the 2008 Kŏn'gukchŏl Dispute can be divided into two separate areas. The first one, dealt with in this section, are the activities occurring in politics and civil society between the filing and the withdrawal of the third draft bill (July-September). The second one, dealt with in the next section, is the dispute taking place in newspapers, in form of articles, columns, essays, etc. Both areas are closely intertwined, but for matters of structure, I decided to separate them into two sections.

In July, the Kŏn'guk Committee, in its presentations for the central events of 8.15, chose to name the central ceremony "60th anniversary of state foundation and 63rd anniversary of kwangbok [...]." On July 29, the Kwangbokhoe 광복회 40 protested the activities and terminology of the Kŏn'guk Committee. On August 1, Kwangbokhoe, together with the three oppositional parties, criticised the government for "neglecting the independence movement," accusing the Kŏn'guk Committee of "violating the constitution." ${ }^{41}$ In the wake of this critique, the government changed the name of the ceremony to "63rd anniversary of kwangbok and 60th anniversary of foundation $[\ldots] . "$

However, continued usage of kŏn'guk in official documents and events persisted. As a result, the weeks leading up to 8.15 saw a sharp increase in protests against the kŏn'guk view. On August 7, fifty-five civic groups related to the independence movement filed an appeal to the constitutional court, claiming that commemoration events under the kŏn'guk view "neglect the continuity between the exile government

\footnotetext{
${ }^{38}$ As analysed in detail in my M.A. thesis, media attention on the issues of kŏn'guk / kŏn'gukchŏl peaked in the first two weeks of August. Most newspaper articles on the issue can be found on August 16 and 17 (cf. Vierthaler 2018: 33-42; 103-105).

39 “Chŏng Kap-yun wiwŏn, kwangbokchŏl $\rightarrow$ kŏn'gukchŏl kaejŏngan ch'ŏrhoe 정갑윤 의원, 광복절 $\rightarrow$ 건국절 개정안 철회," Hankyoreh, September 12, 2008.

${ }^{40}$ Kwangbokhoe is a civic organisation consisting of independence activists and their descendants with the aim to protect an "ethnic spirit" and the friendship among its members. Founded in 1965, it is one of the most influential organisations commemorating the independence movement.

41 "Yadang, Kwangbokhoe 'chŏngbu'ga tongnip undong pujŏng' 야당, 광복회 '정부가 독립운동 부정,," Hankyoreh, August 1, 2008.
} 
and South Korea as clarified in the constitution and therefore are unconstitutional." ${ }^{42}$ On August 11, student protests were reported in Hankyoreh. ${ }^{43}$ On August 13, various democratisation movement-related civic groups in a press conference demanded the term chóngbu surip to be used when referring to August 15, 1948. ${ }^{44}$ On August 14, the Democratic Party (the biggest opposition party by then) released a memorandum criticising official commemoration events to be "anti-historical" and "against Korean ethnic history." ${ }^{45}$ The same day, KBS released an opinion poll on the kŏn'gukchŏl issue. According to this poll, only 21.1 per cent approved the proposed re-naming, whereas 67.1 per cent of respondents opposed it (Yi WB 2009: 85). This is a significantly different result than the one published two years earlier by Chosun ilbo and can be interpreted as a first consequence of the discourse in media and society following the politicisation of the kŏn'guk view.

For the issue to arise as a serious dispute, the most-crucial blow came in form of broad resistance by specialised historians against the kŏn'guk terminology. On August 12, a memorandum signed by fourteen historical societies was published in Yǒksa Pip'yŏng 역사비평 [Critical Review of History]. ${ }^{46}$ A major journal on Korean contemporary history, Yǒksa Pip'yŏng published special features on the establishment of the Northern and Southern governments and its legacy throughout its four issues of 2008. As early as in the foreword to the spring issue (no. 82, February), the journal adopted an editorial stance opposed to using of kŏn'guk when referring to the August 15, 1948; instead, it preferred using (nambuk) chŏngbu surip. ${ }^{47}$ An identical editorial stance and focus on the legacy of 2008 was adopted by Naeir'ǔl Yŏnŭn Yŏksa 내일을 여는 역사 [History to Open Tomorrow], another major journal focused on Korean

42 “55-gae tanch'e 'kŏn'gukchŏr'ŭn imjŏng pŏpt'ong pujŏng wihŏn' hŏnso 55 개 단체 '건국절은 임정 법통 부정 위헌' 헌소”, Kyunghyang sinmun, August 7, 2008. The appeal was turned down by the constitutional court on November 27. Cf. "Taehan min'guk kŏn'guk 60-nyŏn kinyŏm saŏp wiwŏnhoe'ŭi sŏlch'i mit unyŏng'e kwanhan kyujŏng wihŏn hwagin 대한민국건국 60 년기념사업위원회의 설치 및 운영에 관한 규정 위헌확인," case no. 2008 헌마 517, November 27, 2008, Constitutional Court of Korea.

43 'Sŏuldae-saengdŭl 'kŏn'guk 60-chunyŏn haengsa pandae' 서울대생들 '건국 60 주년 행사 반대,', Hankyoreh, August 11, 2008.

44 “Yi Myŏng-bak chŏngbu, 'pan'gong, sijang chisangjuŭi', Nyurait'ŭ'wa p'anbagi 이명박 정부, ‘반공, 시장지상주의' 뉴라이트와 판박이,” Hankyoreh, August 14, 2008.

45 “Chŏng Se-kyun “'kŏn'gukchŏl kido”'nŭn pan-yŏksa / pan-minjok'chŏk ch’ŏsa' 정 세균 “건국절 기도'는 반역사·반민족적 처사"”, Chosun ilbo, August 14, 2008.

46 “'Kŏn'gukchŏl' ch’ŏrhoe'rŭl ch'okku hanŭn yŏksa hakkye'ŭi sŏngmyŏngsŏ '건국절' 철회를 촉구하는 역사학계의 성명서," 역사비평 Yǒksa Pip'yŏng, 84, p. 14.

47 "Nambuk chŏngbu surip 60-chunyŏn'gwa sae-chŏngbu ch'ulbŏm 남북정부 수립 60 주년과 새정부 출범”, 역사비평," Yǒksa Pip’yŏng, 82, pp. 6-14. 
contemporary history. ${ }^{48}$ Similarly, other academic journals on (Korean) history saw the publication of articles critically dealing with the kŏn'guk view.

The memorandum published on August 12 strongly criticises not only the attempts to re-name 8.15 , but also the way the Kŏn'guk Committee approached history. For the authors, the 2008 commemoration events are "ignoring the historicity of national memorial days." Unlike the draft bill for re-naming 8.15, the authors argued that the term kwangbokchŏl itself both incorporates the meanings of "liberation" (1945) and "proclamation of the state" (1948). Furthermore, history "is not created at will by [individual] politicians or by the sole judgements of only parts of the academic community, $[\ldots]$ but by a huge number of research and discussion among scholars [...]." In other words, for the historians signing the memorandum, the activities of the Kŏn'guk Committee and the attempts to re-name 8.15 did not present history, but a mere ignorance of history. ${ }^{49}$

Despite these events, the central commemoration events were carried out as planned on August 15, 2008. At Kanghwamun gate in the heart of Seoul, on the grounds of Kyŏngbokgung palace, the event consisted of a speech by Lee Myung-bak, followed by a parade to Seoul City Hall. However, due to the official name of the ceremony containing the term kón'guk, the opposition as well as parts of the independence movement civic groups boycotted the ceremony. Instead of unifying society, as argued by advocates of the konn'guk view, the attempted re-framing of 8.15 had the opposite effect.

The three opposition parties held their own ceremony at the grave of $\mathrm{Kim} \mathrm{Ku},{ }^{50}$ whereas some civic groups held a commemoration ceremony at T'apgol park (T'apgol kongwŏn 탑골공원/塔谷公園) near Insadong in central Seoul. Some of the groups attended a reception with Lee Myung-bak at the Blue House but held their own ceremony at the Seoul Museum of History, celebrating not the sixtieth anniversary of state foundation but the eighty-nineth.

In his commemoration speech, Lee Myung-bak presented South Korean history based on the kón'guk view. ${ }^{51}$ Despite the name-change to commemorate sixty-three years of kwangbok and sixty years of kŏn'guk, Lee's speech focused on the importance of 1948 for South Korea, presented in a terminology very close to the New

\footnotetext{
48 “Tangsindŭr'ǔi ch'ŏnguk, Taehan min'guk 당신들의 천국, 대한민국,” Naeir'ŭl Yŏnŭn Yŏksa, 31, pp. 10-15.

49 'Kŏn'gukchŏl' ch'ŏrhoe'rŭl ch'okku hanŭn yŏksa hakkye'ŭi sŏngmyŏngsŏ '건국절' 철회를 촉구하는 역사학계의 성명서," 역사비평 Yǒksa Pip'yŏng, 84, p. 14.

${ }^{50} \mathrm{Kim} \mathrm{Ku}(1876-1949)$ was an independence activist and right-wing politician. A major rival to Syngman Rhee, Kim Ku boycotted the May 1948 elections and argued for the establishment of a unified government. He was murdered in front of his house in 1949.

51 “Che-63-chunyŏn kwangbokchŏl mit Taehan min'guk kŏn'guk 60-nyŏn kyŏngch'uksa 제 63 주년 광복절 및 대한민국 건국 60 년 경축사,” Presidential Speech, August 15, 2008, Presidential Archives.
} 
Right's intellectual thoughts (cf. Chŏng 2006). The events of 1945 (kwangbok) were mentioned only twice, whereas foundation (kŏn'guk) was mentioned nine times. For Lee, South Korean history has to be seen as one in which "liberalism and market economy developed," which in other words was "a history of success," "a miraculous history." History should not "face the past" but "develop future-oriented." In this regard, large parts of Lee's speech did not focus on the meaning of 8.15 in South Korean history, but on challenges ahead. Rather than commemorating the past, Lee tried to paint a vision of his upcoming presidential term, by again naming the process of "advancing" (sŏnjinhwa) as a major goal of his policy. Therefore, Lee's speech can be called a policy direction speech rather than a commemoration speech.

Following the central commemoration events, both the progressive daily newspapers Hankyoreh and Kyunghyang sinmun strongly criticised the contents of Lee Myung-bak's speech. For Hankyoreh, the central issue following 8.15 was not about just whether to call 8.15 kón'gukchŏl or not, but how the dispute regarding the narration of 8.15 brought along further division both between the North and the South and within South Korean society. ${ }^{52}$ By celebrating solely the foundation of South Korea, South Korean history ran into the danger of becoming only a "history of a conservative, right-wing state." Kyunghyang sinmun more generally criticised the performance of Lee Myung-bak's presidency: focusing on re-framing 8.15 "ignores public sentiment," being a testimony that Lee's government is "six months of failure." 53

On the other hand, in an editorial on August 14, the conservative Chosun ilbo argued that "kwangbok and kón'guk ought to be closely examined together." ${ }^{54}$ For Chosun ilbo, the Roh government's historical reconciliation policies "were trampling on the founding history [kón'guksa 건국사/建國史]" and education and research "have fallen into left-extreme ideas"; therefore, "correcting [these views] is natural, the miraculous achievements of industrialisation and democratisation are the very history of South Korea."

\section{The 2008 Kŏn'gukchŏl Dispute in Newspapers}

For a closer analysis of the dispute resulting from the attempt to re-name 8.15 and the central commemoration ceremony based on the kŏn'guk view, four major Korean newspapers have been analysed for this paper. The results of a quantitative analysis show the following results: (1) Reporting on the kŏn'gukchŏl issue was largely non-

\footnotetext{
52 “(Sasŏl) Kwangbokchŏr'ŭl tchijŏnoŭn Yi Myŏng-bak chŏngbu (사설) 광복절을 찢어놓은 이명박 정부," Hankyoreh, August 15, 2008.

53 “(Sasŏl) Yi taet'ongnyŏng'ŭn 'silp'ae han 6-kaewŏl' toep'uri haryŏnŭnga' (사설) 이 대통령은 '실패한 6 개월' 되풀이하려는가,” Kyunghyang sinmun, August 16, 2008.

54 “(Sasŏl) Kwangbok'kwa kŏn'gug'ǔi ŭimi'rŭl kat'i] saegigo hamkke ŭmmi haeya (사설) 광복과 건국의 의미를 같이 새기고 합께 음미해야," Chosun ilbo, August 14, 2008.
} 
existent before July 2008. However, following the third draft bill, the issue began to appear in all four discussed newspapers and peaked in August; (2) the 2008 Kŏn'gukchŏl Dispute in newspapers ended in September, following the withdrawal of the draft bill; however, a number of articles continued to appear in Hankyoreh and Kyunghyang sinmun into December; (3) the dispute received most attention in Hankyoreh with sixty-six articles, followed by Kyunghyang sinmun with twenty-six, Chosun ilbo with eleven, and Tonga ilbo with ten articles. ${ }^{55}$

\section{A) Hankyoreh and Kyunghyang sinmun: Opponents to the kŏn'guk View}

Among the four analysed newspapers, Hankyoreh did not only publish most of the articles on the subject (four in July, forty-two in August, seven in September) - it was also the most critical. Besides branding the kŏn'guk view as a neglect of the independence movement and of Syngman Rhee's own historical views (see above), the introduction of a kŏn'gukchŏl in the eyes of Hankyoreh constitutes a "celebration of the achievements of colonial rule," narrating South Korean history "through the lens of collaborators." ${ }^{56}$ With the re-narration of 8.15 , Lee Myung-bak "destroyed kwangbokchŏl [as a memorial day]," ${ }^{, 7} 8.15$ therefore becoming a "day of celebration for collaborators." The kŏn'guk view, for Hankyoreh, is not different from that of Japanese revisionists. ${ }^{58}$

Hankyoreh did not only publish articles supporting its own editorial stance, but also reported dissenting opinions on the kŏn'gukchŏl issue within the ruling Hannara Party, ${ }^{59}$ and an interview with Hyŏn Kyŏng-byŏng 현경병, one of the proposers of the third draft bill. In the interview Hyŏn argued that, while "history always consists of light and shadows," re-naming 8.15 into kŏn'gukchŏl means to "commemorate the introduction of democracy and market economy to Korea instead of focusing on commemorating political separation," which Hyŏng deemed to be a "masochistic interpretation of history. ${ }^{60}$ Hyŏn also pointed out what was later to become a key argument in the New Right's theoretical foundation of the kŏn'guk view (e.g., Kim

55 Analysed period: November 19, 2007 to December 29, 2008. Analysed keywords: (A): kŏn'gukchŏl; (B) kŏn'guk 60nyŏn; (C) kŏn'guk 60junyŏn. For details, cf. Vierthaler 2018: 103-105. 56 “(Sasŏl) 'Kŏn'guk”i anira “chŏngbu surip”'i olt'a (사설) '건국'이 아니라 ‘정부수립’이 옳다," Hankyoreh, August 4, 2008.

57 “(Sasŏl) Kwangbokchŏr'ŭl tchijŏnoŭn Yi Myŏng-bak chŏngbu (사설) 광복절을 찢어놓은 이명박 정부”, Hankyoreh, August 16, 2008.

58 “Tokto'nŭn Ilbon ttang ida / chŏng'ŭi kil 독도는 일본 땅이다 / 정의길," Hankyoreh, August 17, 2008.

59 "Hannara Song Kwang-ho 'hyŏng-hwakchŏng 5-gaewŏl andoen samyŏn'ŭn munje' 한나라 송광호 '형 확정 5 개월 안된 사면은 문제'," Hankyoreh, August 12, 2008.

60 "Hyŏn Kyŏng-byŏng 'Sanghai imsi chŏngbu'nŭn ŏdi kkajina 'imsi', 현경병 '상하이 임시정부는 어디까지나 “임시”," Hankyoreh, August 13, 2008. 
Yŏng-ho, Kim Il-yŏng, and Yang Tong-an 양동안): that 1948 marks the year when South Korea became an independent nation-state under international law, as opposed to the provisional government in Shanghai, which lacked any diplomatic recognition and therefore "was provisional to the last."

Furthermore, Hankyoreh published three articles written by historians specialised in Korean modern and contemporary history on the kŏn'guk (chŏl) issue. Kang Mangil 강만길, one of the key scholars of the reunification-oriented contemporary history (Em 2013: 152-155), calls the kón' guk view to be "a neglect of modern and liberation period history." ${ }^{61}$ Han Si-jun, a scholar on the independence movement and the provisional government, argues that the kŏn'guk view's argumentation is "impossible regarding legal, historical and sociological terms," with 2008 not marking the sixtieth anniversary of the foundation (kon'guk) of South Korea but the eighty-ninth. ${ }^{62}$ Han Hong-gu, a key member of the Truth and Reconciliation Committee, more generally criticises the New Right narration of history as an attempt of the heirs of the proJapanese collaborators to justify political division and the failure of purging proJapanese elements in 1948-1949 from a contemporary point of view of economic success; or, as Han argued, to "justify the first South Korean coup d'état carried out by the ch 'inilp' a' in 1948-1949. ${ }^{63}$

In Kyunghyang sinmun the number of articles dealing with the kŏn'gukchŏl issue is significantly lower compared to Hankyoreh, but the basic argumentation is quite similar. In an editorial on August 4, Kyunghyang sinmun sees the core of the dispute in the historical evaluation of the issue of independence movements and colonial modernity and how New Right scholars, like Yi Yŏng-hun, are "trying to incorporate these views [into public memory and official history] without common consent among citizens. ${ }^{, 64}$ Furthermore, the kŏn'guk view is tied to narrating Syngman Rhee

61 “[Int’ŏbyu] Sahakkye wŏllo Kang Man-gil myŏngye kyŏsu [인터뷰]사학계 원로 강만길 명예교수," Hankyoreh, August 10, 2008.

62 "Sŏllip toel su ŏmnŭn 'kŏn'guk 60-nyŏn' / Han Si-jun 성립될 수 없는 '건국 60 년' / 한시준," Hankyoreh, August 11, 2008. As Han later on elaborates in more detail (Han 2017), 1948 rather marks the "re-establishment" (chaegŏn 재건/再建) of South Korea, not only because of continuity in constitutional terms (see above), but also because of its choice of name (Taehan min'guk) and era name used in official documents. Sociologically, Han argues that similar institutions in Korea, which were dissolved and/or re-named at some point in their history, assess the moment of initial establishment as their foundation date. For example, Korea University was founded in 1905 as Bosung College and became Korea University only in 1946, but nevertheless celebrated its one-hundredth anniversary in 2005. For the above reasons, if there was to be a date for the foundation of the modern (South) Korean nation-state, it had to be 1919 (independence declaration and Shanghai provisional government) and not 1948, therefore making the kón' 'guk view's argumentation null and void.

63 "Han Hong-gu kyosu'ŭi 'Taehan min'guksa t'ǔkkang' 한홍구 교수의 '대한민국사 특강'," Hankyoreh, October 17 - December 5, 2008 (eight instalments).

64 “(Sasŏl) Kwangbokchŏl'to 'kŏn'gukchŏl'lo mirŏbut'iryŏ hana (사설) 광복절도 '건국절'로 밀어붙이려 하나,” Kyunghyang sinmun, August 4, 2008. 
as the "father of the nation," as well as "a reinstatement of anti-communist state doctrine in combination with authoritarianism and a growth-above-all ideology." $" 65$ That the opposition and various independence movement civic groups held their own commemoration events of 8.15 for Kyunghyang sinmun is a "sad" and "confused" kwangbokchŏl. $^{66}$

\section{B) Chosun ilbo and Tonga ilbo: 1948 kŏn'guk yes, but kŏn'gukchŏl?}

Compared to the two progressive daily newspapers, the overall number of articles dealing with the issue of kön'gukchŏl in August was low in Chosun ilbo (nine) and Tonga ilbo (six). However, Chosun ilbo published a high number of articles dealing with kŏn'guk 60-nyŏn (sixty-seven) or kŏn'guk 60-chunyŏn (107). As the funding of academic conferences supporting the kŏn'guk view by Tonga ilbo (cf. Yi IH 2011) or the editorials of Chosun ilbo on August 15, 2006, 2007, and 2008 (see above) show, both newspapers supported the kŏn'guk view and the Kŏn'guk Committee's approach to the state commemoration events. However, as the analysis below reveals, they did so in different ways.

Tonga ilbo was rather conscious with using the word kon'guk as opposed to the more accepted term of promulgation of the government (chŏngbu surip) in its articles. While not referring to the events of 1948 as kŏn'guk, Tonga ilbo nevertheless supported the focus of the state commemoration events on 1948 rather than $1945 .{ }^{67}$ At the same time, however, Tonga ilbo criticised the proposed re-naming of 8.15 into kŏn'gukchŏl, naming it "a mere extremist opinion amongst a handful far-right." ${ }^{\text {" }}$ In other words, while Tonga ilbo's editorial stance supported the focus of 2008's commemoration events on 1948, it did not support the supposed re-naming of 8.15 as a memorial day into kŏn'gukchŏl, nor did the paper actively use the term kŏn'guk. This can partly be explained against the background that Tonga Ilbo, with a history of resistance during the colonial period as well as the Yusin regime, cannot possibly support full-heartedly the re-naming of a memorial day commemorating liberation. However, as Ha Chong-mun (2007: 177-184) points out, Tonga ilbo was the first newspaper to use the term "masochistic history" in September 2004. It also was the newspaper actively reporting on the New Right during their days of foundation, providing them with a stage for their thoughts (Chŏng 2006: 215-220). Thus, while

\footnotetext{
65 “(Sasŏl) Yi taet'ongnyŏng'ŭn 'silp'ae han 6-kaewŏl' toep'uri haryŏnŭnga (사설) 이 대통령은 '실패한 6 개월' 되풀이하려는가,” Kyunghyang sinmun, August 15, 2008.

66 “Tup'yŏn'ŭro kallajin 'sŭlp'ŭn kwangbokchŏl' 두편으로 갈라진 '슬픈 광복절'," Kyunghyang sinmun, August 14, 2008; “Chŏngbu 'kŏn'guk ch'ukche chunbi' ... hollansŭrŏun kwangbokchŏl 정부 ‘건국축제 준비' $\cdots$ 혼란스러운 광복절”, Kyunghyang sinmun, August 12, 2008.

67 “(Sasŏl) Minjudang, 'kŏn'guk”'kwa 'che-2 kŏn'guk'ŭn ŏttok'e tarŭnga (사설) 민주당, '건국'과 '제 2 건국'은 어떻게 다른가,” Tonga ilbo, August 17, 2008.

${ }^{68}$ Ibid.
} 
not actively advocating the use of kŏn'guk(chŏl), Tonga ilbo nevertheless played an important role in advocating the New Right.

On the other hand, Chosun ilbo took a highly positive stance towards the issue. As shown above, the paper strongly supported the kŏn'guk view and openly used the term kŏn'guk. For Chosun ilbo, sixty years of South Korean history are mythical: "There were numerous hardships and conflicts. However, those were overcome [...]. To this day, with the exemption of the developed nations, there is no democracy like South Korea. This is $[\ldots]$ the South Korean myth $[\ldots]$ and lets us fully realise just how accurate the decisions made by the founding fathers were." ${ }^{\prime 69}$ For Chosun ilbo, South Korean history is a fundamentally positive one, attributed to its "founding fathers" (Syngman Rhee, Park Chung-hee).

Among the low number of articles dealing with the kŏn'guk view in both newspapers, two pieces by scholars elaborating on the kón'guk view worthy of an analysis were published. On August 1, Kim Sŏng-ho 김성호, a professor of political thought at Yonsei University, elaborated on the kŏn'gukchŏl issue from the concepts of chŏngt'ongsŏng 정통성/正統性 and chŏngdangsŏng 정당성/正当性. ${ }^{70}$ Both terms are usually translated as "legitimacy," but Kim uses the English translations of "orthodoxy" for the former and "legitimacy" for the latter in his essay. For Kim, the debate on the foundation of (South) Korea was one on historical continuity. From an ethnic perspective, as an ancient state, "orthodoxy" represents a "diachronic concept for foundation." In South Korean terms, orthodoxy with the ethnic nation is provided by continuity with the independence movement and the provisional government as written in the founding constitution's preamble. "Legitimacy" on the other side is defined by Kim as a "synchronous concept," "deriving from continuous and voluntary acceptance among citizens." In South Korean context, the elections of May 1948 and diplomatic recognition by the UN in December of the same year "provide the modern nation-state [of South Korea] with legitimacy." Therefore, there is no problem for 1948 to be interpreted as the year of "foundation" of South Korea, since the term kón'guk can both point to 1919 and 1948.

On August 11, Yi In-ho, as an important proponent of the kŏn'guk view and a principal member of the commemoration committee, acknowledged that the Kŏn'guk Committee's activities lacked proper recognition in wide parts of society and that its thoughts and ideas need to be "sorted more straightforward and clearly." ${ }^{71}$ However, $\mathrm{Yi}$ at the same time defends herself against critics, arguing that they "misunderstand"

\footnotetext{
69 “(Sasŏl) Kwangbok'kwa kŏn'guk'ŭi ŭimi'rŭl kat'i saegigo hamkke ŭmmi haeya (사설) 광복과 건국의 의미를 같이 새기고 합께 음미해야," Chosun ilbo, August 15, 2008.

70 “(Tonga kwangjang / Kim Sŏng-ho) 1919-nyŏn chŏngt'ongsŏng vs 1948-nyŏn chŏngdangsŏng (동아광장/김성호) 1919 년 정통성 Vs 1948 년 정당성," Tonga ilbo, August 1, 2008.

71 “(Yi In-ho k'allŏm) Taehan min'guk, charangsŭrŏun nara ta (이인호 칼럼) 대한민국, 자랑스러운 나라다," Tonga ilbo, August 11, 2008.
} 
the Kŏn'guk Committee's aims. For Yi, the kŏn'guk view does not neglect the independence movements' history; rather it celebrates the "establishment of a republican state."

\section{The MCST Booklet and the Dispute Shifting to Academics}

Following the intense discussion on how (not) to place 8.15 in public memory in the summer of 2008, the Kŏn'gukchŏl Dispute quietly faded away in the early weeks of autumn. On September 12, Chŏng Kap-yun formally withdrew the draft bill for renaming 8.15 into kŏn'gukchŏl. Apologising for "causing division and conflict in society," Chŏng also expressed "unfortunate feelings that the genuine aims of the draft bill have been distorted by some" and hoped that this withdrawal leads the dispute to fade away, thereby enabling Lee to focus on his policies. ${ }^{72}$

However, the 2008 Kŏn'gukchŏl Dispute resurfaced in the last weeks of 2008. On December 23, Hankyoreh published an article on the distribution of the MCST booklet Kŏn'guk 60-nyŏn - widaehan kungmin, saeroun kkum (60 years of foundation great citizens, new dreams; Pak et al. 2008) in schools and other public facilities. ${ }^{73}$ The booklet, as stated above, was written by New Right affiliated scholars and narrates South Korean history based on the kón'guk view. Hankyoreh's article was published one day after Lee Myung-bak declared the historical reconciliation policies of the Kim/Roh governments to have "broken South Korean legitimacy." ${ }^{74}$ In its reporting, Hankyoreh not only criticised the contents dealing with 1948, but saw the whole booklet as an attempt to whitewash Syngman Rhee's and Park Chung-hee's autocratic rule. Despite being a historical booklet, one of six chapters was devoted to ideological concepts proclaimed by the New Right and Lee Myung-bak's political slogans and goals (sŏnjinhwa, etc.), whereas the Jeju Incident and the Kwangju Uprising were mentioned only very briefly.

Protests ensued, first by survivors and bereaved families of the Jeju Uprising (December 23) and by the committee to commemorate the provisional government (December 25). ${ }^{75}$ Most critically however, Kwangbokhoe passed a resolution (December 29) to return their Orders of Merit for National Foundation (kŏn'guk hunjang

\footnotetext{
72 “Chŏng Kap-yun wiwŏn, kwangbokchŏl $\rightarrow$ kŏn'gukchŏl kaejŏngan ch’ŏrhoe 정갑윤 의원, 광복절 $\rightarrow$ 건국절 개정안 철회," Hankyoreh, September 12, 2008.

73 “(Tandok) Munhwabu, ‘imjŏng pŏbt'ong musi' ch'aekcha chŏnguk chung/ko paep’o (단독) 문화부, ‘임정 법통무시’ 책자 전국 중·고 배포,” Hankyoreh, December 23, 2008.

74 "Yi Myŏng-bak 'kukka chŏngch'esŏng hweson kip'ta' 이명박 '국가정체성 훼손 깊다,," Hankyoreh, December 22, 2008.

75 "Munhwabu paep'o ch'aekcha '4.3 musi' yujok'tŭl panbal 문화부 배포 책자 '4.3 무시' 유족들 반발," Hankyoreh, December 23, 2008; [Kigo] munhwabu paep'o ch'aekcha'ŭi panminjoksŏng / Kim Cha-dong “[기고] 문화부 배포 책자의 반민족성 / 김자동," Hankyoreh, December 25, 2008.
} 
건국훈장/建國勲章 $)^{76}$ to the state, demanding a formal apology from the Minister of Culture, and the disposal of the distributed booklets. ${ }^{77} \mathrm{Yu} \mathrm{In-ch'on} \mathrm{유인촌,} \mathrm{the}$ Minister of Culture, paid a visit to Kwangbokhoe the same day, offering his "regret" to members of the organisation. ${ }^{78}$ However, Kwangbokhoe did not withdraw its decision to return the medals and instead waited for the MCST to act, sending their own letters to institutions the booklet was distributed to, demanding to sort out and rearrange the "wrong parts."

Following the clash between civil societies and the MCST, the 2008 Kŏn'gukchŏl Dispute ended. The term disappeared from public documents and media thereafter. Also, the mandate of the Kŏn'guk Committee ended on December 31. The 2009 commemoration events were held as the "64th anniversary of kwangbok," with the focus of the events on the 1945 liberation. The name kwangbokchol remains unchanged to this day (April 2018), although a fourth, unsuccessful draft bill to re-name 8.15 was presented in the National Assembly in $2014 .{ }^{79}$ For Ha Sang-bok (2012), the major reason the introduction of a kŏn'gukchŏl failed was because Lee Myung-bak did not consult with specialised historians. Instead, the commemoration events of 2008 were strongly anti-Roh in character and lacking any historical substance.

However, the dispute on how to narrate the events of 1948 in South Korean contemporary history was only about to begin among scholars. Following a collection of lectures published on August 15, 2008 by advocates of the kón'guk view (Kim YH et al. 2008), books and articles were to follow in 2009, leading to the publication of extensive elaborations by the advocates (Yi CY et al. 2011; Kim YH 2015; Yang 2016) and opponents (Han 2017; Yi IJ 2017; Yun 2017) alike in recent years. However, to the present day, a dialogue between both sides has rarely taken place and the issue on how to evaluate the South Korean state foundation remains unresolved.

\section{Conclusion}

In the early 2000s, the emergence of the New Right represented a challenge to intellectual thought in South Korea. Dissatisfied with the policies perceived under the Kim Dae-jung and Roh Moo-hyun governments, the New Right took on the task to re-

\footnotetext{
${ }^{76}$ The kŏn'guk hunjang was established in 1962. It is awarded by the president for outstanding meritorious services in the interest of founding or laying a foundation for South Korea. Around 8,000 people have received the order, most of them posthumously (e.g., $\mathrm{Kim} \mathrm{Ku}$ ).

77 “Kwangbokhoe, kŏn'guk hunjang pannap kyŏrŭi 광복회, 건국훈장 반납 결의,” Hankyoreh, December 29, 2008.

78 “Yu In-ch'on munhwa, 'kŏn'guk nollan' hongbo ch'aekcha yugam p'yomyŏng 유인촌 문화, '건국 논란' 홍보책자 유감 표명,” Hankyoreh, December 29, 2008.

79 “Kukkyŏngir'e kwanhan pŏmnyul ilbu kaechŏng pŏmnyuran 국경일에 관한 법률 일부개정법률안," bill no. 11572, September 2, 2014, The National Assembly Information System.
} 
narrate South Korean contemporary history by changing history textbooks and public memory into a state-centred ideology. A major contested issue was the history and memory associated with the creation of the South Korean state in 1948 and 8.15 as a memorial day. The New Right proposed a historical view narrating the legacy of 8.15 not focused on liberation from colonial rule, ethnical division, and the difficult legacies of colonialism, as was the mainstream narrative up until then, but on the foundation of later economic success and prosperity. Simultaneously, concrete attempts to re-name 8.15 into Foundation Day (kŏn'gukchŏl) emerged.

Shortly after Lee Myung-bak became president, the New Right's interpretation of history became the official narrative of the 2008 South Korean commemoration events. Together with repeated attempts in the National Assembly to re-name 8.15, this previously uncontested aspect of Korean history became widely discussed in politics, civil society, and the media for most of the summer of 2008. Proponents of the view argued for the need to create a "positive view" of history; opponents see in it a whitewashing of history to justify authoritarianism, state violence, and the failure of resolving the collaboration issue in the name of economic success and prosperity while neglecting Korean resistance to colonial rule. For the issue of 8.15 as the foundation day of modern South Korea, the New Right's claims are valid if seen through political eyes. However, this neglects the turbulent years that preceded the establishment of South Korea, the violence and context behind these events. I see in the dispute the clashing of two diametrically opposed academic disciplines: political science strongly influenced by Western concepts of statehood and modernism on the side of the New Right, and an ethnic interpretation of history, highly post-colonial and critical towards the state, in combination with the achievements of twenty years of historical research into the issues of state violence.

In a repetitive struggle for hegemony over narrating official history, the New Right's re-narration of 8.15 presented a serious challenge to established discourse. However, due to broad resistance by historians, the re-naming of 8.15 ultimately failed. This took the dispute into academics, where proponents and opponents of the 1948-centred narrative continue to argue on how to evaluate and place 8.15 up to this day. The central issue in the 2008 Kŏn'gukchŏl Dispute is not whether South Korea was founded in 1948 or not. The dispute rather must be evaluated as a prime example of a non-existing dialogue between two different approaches to narrating history. If asked how to place 8.15 in South Korean history, there is no clear answer: Liberation from colonial rule; establishment of separate governments and division; foundation of the modern South Korean nation-state - they all have their validity and need to be weighed up against each other in professional academic historiography. History is never black and white; it always incorporates complex ways of in-between. It is the task of historians to properly evaluate and narrate complex issues like the legacy of the founding of South Korea. 


\section{PRIMARY SOURCES}

Archives

Constitutional Court of Korea

National Archives of Korea

National Law Information Center

Presidential Archives

The National Assembly Information System

Newspapers

Chosun ilbo

DailyNK

Tonga ilbo

Hankyoreh

Kyunghyang sinmun

Journals, Magazines, TV News

Hankyoreh 21

KBS News

Kwanbo

Kukhoebo

Yŏksa Pip'yŏng

Naeil ŭl yŏnŭn yŏksa http://search.ccourt.go.kr/ths/hm/index.do http://www.archives.go.kr http://www.law.go.kr/ http://www.pa.go.kr http://likms.assembly.go.kr

\section{REFERENCES}

An, Pyŏng-jik 안병직 and Yi Yŏng-hun 이영훈. 2007. Taehan min'guk yŏksa'ǔi kiro'e sŏda 대한민국 역사의 기로에 서다 [Standing at the Crossroads of South Korean History]. Sŏul 서울: Kip'arang 기파랑.

Anderson, Benedict. 1983. Imagined Communities: Reflections on the Origin and Spread of Nationalism. London: Verso.

Billig, Michael. 1995. Banal Nationalism. London: SAGE Publications.

Campbell, Emma. 2016. South Korea's New Nationalism: The End of "One Korea”? Boulder: Lynne Rienner.

Chi, Su-gŏl 지수걸. 2016. "Kŏn'gukchŏl nonjaeng'ŭi chihyŏng pakkugi 건국절 논쟁의 지형 바꾸기 [A Change in the Topography of the Kŏn'gukchŏl Dispute].” Naeir'ŭl Yŏnŭn Yŏksa 내일을 여는 역사 [History to Open Tomorrow], 64, pp. 15-25.

Chŏn, Hyŏn-jun 전현준. 2005. “'Sasang chŏnhyang'ŭl t'onghae punsŏkhan nyŭrait'ŭ: Angdŭre Chidŭ'wa nyŭrait'ŭ'ŭi ch'ai '사상 전향'을 통해 분석한 뉴라이트]앙드레 지드와 뉴라이트의 차이' [The New Right Analysed With the Focus on 'Thought Conversion': André Gide and the New Right].” Wǒlgan Mal 월간말, 1, pp. 66-69.

Chŏng, Hae-gu 정해구. 2006. 'Nyurait'ŭ undong'ŭi hyŏnsil insig'e taehan pip'anjŏk kŏmt'o 뉴라이트 운동의 현실인식에 대한 비판적 검토 [A Critical Examination of the New Right Movement's Awareness of Reality].” Yǒksa Pip'yŏng 역사비평 [Critical Review of History], 76, pp. 215-237.

Chŏng, Pyŏng-chun 정병준. 2017. "Haebang'gwa pundan'ŭi hyŏndaesa tasi ilkki 해방과 분단의 현 대사 다시 읽기 [Re-Reading the Contemporary History of Liberation and Division]." In Pak T'ae-gyun 박태균, ed., Chaengjŏm Hanguksa hyŏndaep'yŏn 쟁점 한국사 현 대편 [Controversial Issues of Korean History: Contemporary Period]. Souul 서울: Ch'angbi 창비, pp. 41-86. 
Chung, Youn-tae. 2002. "Refracted Modernity and the Issue of Pro-Japanese Collaborators in Korea." Korea Journal, 42 (3), pp. 18-59.

Cumings, Bruce. 1981. The Origins of the Korean War. Vol. 1: Liberation and the Emergence of Separate Regimes, 1945-1947. Princeton: Princeton University Press.

Cumings, Bruce. 1990. The Origins of the Korean War. Vol. 2: The Roaring of the Cataract, 19471950. Princeton: Princeton University Press.

Em, Henry. 2013. The Great Enterprise: Sovereignty and Historiography in Modern Korea. Durham and London: Duke University Press.

Gellner, Ernest. 1983. Nations and Nationalism. Oxford: Basil-Blackwell.

Ha, Chong-mun 하종문. 2007. "Pan-il minjokjuŭi'wa nyurait' ŭ 반일민족주의와 뉴라이트 [AntiJapanese Ethnic Nationalism and the New Right].” Yǒksa Pip'yŏng 역사비평 [Critical Review of History], 78, pp. 175-197.

Ha, Chong-mun 河棕文. 2010. “Kankoku ni okeru kakoji seisan to rekishi ronsō 韓国における過去 事清算と歴史論争 [Historical Reconciliation and Historical Disputes in South Korea].” Sensō Sekinin Kenky $\bar{u}$ 戦争責任研究 [Research in War Responsibility], 66, pp. 33-43.

Ha, Sang-bok 하상복. 2012. "Yi Myŏng-bak chŏngbu'wa '8.15' kinyŏmir'ŭi haesŏk: posu'ŭi wigi ŭisik'kwa tamron chŏngch'i 이명박 정부와 ' 8.15 '기념일의 해석: 보수의 위기의식과 담론정치 [The Yi Myŏng-bak Government and Its Interpretation of the Memorial Day August 15: Conservative Crisis Awareness and Political Discourse]." Hyŏndae Chŏngch'i Yŏn'gu 현 대정치연구 [Research in Contemporary Politics], 5 (2), pp. 109-132.

Han, Hong-gu 한홍구. 2009. T'ǔkkang: Han Hong-g' ǔi Han'guk hyŏndaesa iyagi 특강: 한홍구의 한국 현 대사 이야기 [Special lecture: Han Hong-gu's South Korean Contemporary History]. Sŏul 서울: Han'gyŏre ch'ulp'ansa 한겨레출판사.

Han, Si-jun 한시준. 2017. Yŏksa nongdan: 1948nyŏn kŏn'guknon'gwa kŏn'gukchŏl 역사 농단: 1948 년 건국론과 건국절 [Monopolisation of History: The 1948 kŏn'guk View and kŏn'gukchŏl]. Sŏul 서울: Yŏksa kong'an 역사공간.

Im, Tae-sik 임대식. 2005. "Kwagŏsa naejŏn'ŭl ap'tugo 과거사 내전을 앞두고 [Having Ahead a Civil War on Past Affairs].” Yǒksa Pip’yŏng 역사비평, 71, pp. 16-31.

Kim Chŏng-in 김정인. 2016. Yǒksa chŏnjaeng: kwagŏ'rŭl haesŏk hanŭn ssaum 역사 전 쟁, 과거를 해석하는 싸움 [History Wars: The Struggle Over the Interpretation of the Past]. Sŏul 서울: Chaeksesang 책세상.

Kim Chŏng-in 김정인. 2017. “Chŏnhyang uik punsŏk: 'puk”'e kŭngŏhan p'ŭreim'gwa kwŏllyŏk yongmang 전향우익 분석: ‘북(北)'에 근거한 프레임과 권력 욕망 [An Analysis of the Convert Rightists: The North Korea Frame and the Thirst for Power].” Munhwa kwahak 문 화과학, 91, pp. 84-105.

Kim, Dong-Choon [=Kim, Tong-ch'un]. 2010. "The Long Road Toward Truth and Reconciliation: Unwavering Attempts to Achieve Justice in South Korea." Critical Asian Studies, 42 (4), pp. $525-552$.

Kim, Ho-gi 金皓起. 2004. “Pip'anjŏk sigag'esŏ pon nyurait’ŭ undong 비판적 시각에서 본 뉴라이트 운동 [The New Right Movement Seen Through a Critical Perspective].” Kwanhun Chŏnŏl 관훈저 널, 45 (4), pp. 148-156.

Kim, Pyŏng-gon 김병곤. 2011. "Han'guk posujuŭi’ŭi inyŏmjŏk t’ŭkjing: kŭndaehwa'ŭi kwangye'rŭl chungsim'ŭro 한국 보수주의의 이념적 특징: 근대화와의 관계를 중심으로 [The Ideological Particularities of Korean Conservatism: Its Relationship to Modernisation].” Yŏksa Pip'yŏng 역사비평, 95, pp. 8-35.

Kim, Tong-ch'un 김동춘. 2015. Taehan min'gug'ün wae? 1945-2015 대한민국은 왜? 1945-2015 [Why South Korea? 1945-2015]. Sŏul 서울: Sagyejŏl 사계절. 
Kim, Yŏng-ho 김영호, ed. 2008. Taehan min'guk kŏn'guk 60-nyŏn'ǔi chaeinsik 대한민국 건국 60 년 의 재인식 [A Re-Interpretation of 60 Years Since the Foundation of South Korea]. Sŏul 서울: Kip'arang 기파랑.

Kim, Yŏng-ho 김영호. 2015. Taehan min'gug'ǔi kŏn'guk hyŏngmyŏng 대한민국의 건국혁명 [The Founding Revolution of South Korea]. 2 vols. Sŏul 서울: Sŏngsin yŏja taehakkyo ch'ulp'anbu 성 신 여 자 대학 교 출 판 부.

Ko, Chi-hun 고지훈. 2008. “'Kŏn'gug',ŭl parabonŭn tu kaji sisŏn: ellit'ŭ'wa minjung '건국'을 바라보는 두 가지 시선 : 엘리트와 민중 [Two Views to Look at the Foundation: The Elite and Minjung].” Yǒksa Pip'yŏng 역사비평 [Critical Review of History], 84, pp. 192-227.

Koseki, Takashi 小関隆. 1999. “Komemoreishon no bunkashi no tame ni コメモレイションの文化史の ために [For a Cultural History of Commemoration].” In Yasunari Abe et al., eds., Kioku no katachi: komemoreishon no bunkashi 記憶のかたち : コメモレイションの文化史 [The Shape of Memory: a Cultural History of Commemoration]. Tōkyō 東京: Kashiwa shobō 柏書房, pp. 5-22.

Koseki, Takashi 小関隆. 2007. “Kinenbi to kinen gyōji wo meguru kōsō 記念日と記念行事をめぐ る抗争 [Conflicts over Commemoration Days and Commemorative Ceremonies].” In Takashi Koseki, ed., Kinenbi no sōzō 記念日の創造 [The Creation of Commemoration Days]. Kyōto 京 都: Jinbunshoin 人文書院, pp. 5-19.

Lee, Namhee. 2008. The Making of Minjung: Democracy and the Politics of Representation in South Korea. Ithaca: Cornell University Press.

Mun, Kyŏng-su 文京洙. 2015. Shin kankoku gendaishi 新・韓国現代史 [A New Contemporary History of South Korea]. Tōkyō 東京: Iwanami shoten 岩波書店.

Nora, Pierre ノラ、ピエール. 2002. “Kioku to rekishi no hazama ni 記憶と歴史のはざまに [Between History and Memory].” In Pierre Nora, ed., Kioku no ba 記憶の場 [Places of Memory]. Vol. 1. Tōkyō 東京: Iwanami shoten 岩波書店, pp. 29-56.

Pak, Ch'an-p'yo 박찬표. 1997. Han'gug'ǔi kukka hyŏngsŏng'gwa min'jujuŭi: migunjŏnggi chayu minjujuüi'ǔi ch'ogi chedohwa 한국의 국가형성과 민주주의: 미군정기 자유민주주의의 초기제도화 [The Formation of the South Korean State and Democracy: The Institutionalisation in the Early US Occupation]. Sŏul 서울: Koryŏ taehakkyo ch'ulp'anbu 고려대학교출판부.

Pak, Chi-hyang 박지향, Kim Ir-yŏng 김일영, Kim Ch’ŏl 김철, and Yi Yŏng-hun 이영 훈, eds. 2006. Haebang chŏnhusa'üi chaeinsik 해방 전후사의 재인식 [Reconsideration of Korean History Before and After Liberation]. 2 Vols. Sŏul 서울: Ch'aeksesang 책세상.

Pak, Hyo Chong 박효종, Kang Kyu-hyŏng 강규형, Kim Yŏng-ho 김영호, Kim Ir-yŏng 김일영, An Hye-ri 안혜리, Chŏn Sang-in 전상인, and Hŭng Chŏng-sŏn 흥정선. 2008. Kŏn'guk 60nyŏn: widaehan kungmin, saeroun kkum 건국 60 년 : 위대한 국민 - 새로운 꿈 [60 Years of Foundation: Great Citizens, New Dreams]. Seoul: Ministry of Culture, Sport, and Tourism [distributed to public institutions, not available in retail stores].

Pak, T'ae-gyun 박태균. 2012. “Segyehwa sidae Han'guk'chŏk inyŏm chihyang'ŭi kiwŏn: t'alnaengchŏn sigi chŏnhu yŏksa insik pyŏnhwa'rŭl chungsim'ŭro 세계화시대 한국적 이념지향의 기원: 탈냉전시기 전후 역사인식 변화를 중심으로 [The Roots of Korean Ideological Orientation in an Age of Globalisation: Focusing on the Changes in Historical Views Before and After the Post-Cold War Period]." In Pak An-hui 박안휘 et al., eds., T'alnaengchŏnsa'ǔi insik 탈냉전사의 인식 [Perceptions of Post-Cold War History]. Sŏul 서울: Hangilsa 한길사, pp. 495-524.

Shin, Ju Baek [= Sin, Chu-baek]. 2005. "Perception of August 15 Remembered in and Forgotten from Korean Textbooks." The Review of Korean Studies, 8 (1), pp. 51-84.

Sin, Chu-baek 신주백. 2006. “Kyogwasŏ p'orŏm'ŭi yŏksa insik pip'an: 'Han'guk kŭn/hyŏndaesa' kyogwasŏ pip'an'e taehan pallon 교과서포럼의 역사인식 비판: 『한국 근 · 현대사』 교과서 비판에 대한 반론 [A Critic of the Textbook Forum's Historical Views: Objections to 
the Critic against the 'Korean Modern/Contemporary History' Textbooks]." Yǒksa Pip'yŏng 역사비평 [Critical Review of History], 76, pp. 181-214.

Sin, Yong-ok 신용옥. 2016. “Taehan min'guk chehŏn hŏnbop'gwa 'kŏn'gukchŏl' nollan 대한민국 제헌헌법과 '건국절' 논란 [The Founding Constitution of South Korea and the "kŏn'gukchŏl" Dispute]." Han'guk sahakpo 한국사학보 [Journal of Korean History], 65, pp. 481-526.

Sŏ, Chung-sŏk 서중석. 2009. "Haebang'gwa Taehan min'guk surip 해방과 대한민국 정부 수립 [Liberation and the Promulgation of South Korea].” In Han Hong-gu 한홍구 et al., eds., Taehan min'gug'ǔi chŏngt'ongsŏr' ŭl mutta 대한민국의 정통성을 묻다 [Questioning the Legitimacy of South Korea]. Sŏul 서울: Ch'ŏlsu'wa yŏnghŭi 철수와영희, pp. 183-231.

Song Kŏn-ho 송건호 et al. 1979-1989. Haebang chŏnhusa'ǔi insik 해방 전후사의 인식 [Perceptions of Korean History Before and After Liberation]. 6 Vols. Sŏul 서울: Hangilsa 한길사.

Suh, Jae-Jung. 2010. "Truth and Reconciliation in South Korea: Confronting War, Colonialism, and Intervention in the Asia Pacific." Critical Asian Studies, 42 (4), pp. 503-524.

Vierthaler, Patrick. 2018. "Kankoku no "kenkokusetsu" dōnyū wo meguru rekishi ninshiki no sōkoku: nyūraito to rekishi kenkyū 韓国の「建国節」導入をめぐる歴史認識の相克一ニューライト と歴史研究 [Discrepancies in the Understandings of History Regarding the Introduction of a kŏn'gukchŏl in Korea: The New Right and Historiography].” M.A. thesis, Kyōto University, Japan.

Yang, Tong-an 양동안. 2001. Taehan min'guk kŏn'guksa 대한민국건국사 [Foundation History of South Korea]. Sŏul 서울: Hyŏnŭmsa 현음사.

Yang, Tong-an 양동안. 2016. Taehan min'guk kŏn'guk'il'gwa kwangbokchŏl koch'al 대한민국 건국일과 광복절 고찰 [An Examination on the Foundation Date of South Korea and kwangbokchŏl]. Sŏul 서울: Paengnyŏndongan 백년동안.

Yi, Chu-yŏng 이주영, ed. 2011. Taehan min'gug'ŭn wae kŏn'guk'ŭl ki'nyŏm haji annŭnka 대한민국은 왜 건국을 기념하지 않는가 [Why is South Korea not Commemorating its Foundation?]. Sŏul 서울: Nyu deilli 뉴데일리.

Yi, In-jae 이인재. 2017. Kŏn'gukchŏl'gwa sonyŏsang: yŏksa kukchŏng kyogwasŏ yugam 건국절과 소녀상 역사 국정교과서 유감 [Kŏn'gukchŏl and Comfort Women Statues: The Regrettable Nationalised History Textbooks]. Sŏul 서울: Hean 혜안.

Yi, In-ho 이인호, Kim Yŏng-ho 김 영호, and Kang Kyu-hyŏng 강규형, eds. 2009. Taehan min'guk kŏn'gug' 'üi chaeinsik 대한민국 건국의 재인식 [A Re-Interpretation of the Foundation of South Korea]. Sŏul 서울: Kip'arang 기파랑.

Yi, Wan-bŏm 이완범. 2009. “Kŏn'guk kijŏm nonjaeng: 1919-nyŏnsŏl'gwa 1948-nyŏnsŏl'ŭi yangnip 건국 기점 논쟁: 1919 년설과 1948 년설의 양립 [The Dispute on the Starting Point of the Foundation: The Coexistence of the 1919 Theory and the 1948 Theory]." Hyonsang'gwa insik [Phenomenon and Awareness], 33 (4), pp. 71-90.

Yi, Yŏng-hun 이영훈. 2007. Taehan min'guk iyagi 대한민국 이야기 [The Story of South Korea]. Sŏul 서울: Kip'arang 기파랑.

Yi, Yŏng-hun 이영훈. 2011. "Kŏn'guk kiŏg'ŭi 60-nyŏn'ŭi paljach'wi 건국 기억의 60 년간의 발자취 [The Footprints of Sixty Years of Memory on the Foundation].” In Yi Chu-yŏng 이주영, ed. 2011. Taehan min'gu'gŭn wae kŏn'gug'ǔl ki'nyŏm haji annünka 대한민국은 왜 건국을 기념하지 않는가 [Why is South Korea not Commemorating its Foundation?]. Sŏul 서울: Nyu delli 뉴데일리, pp. 43-107.

Yu, Yŏng-ik 유영익. 1998. Sujŏngjuŭi'wa Han'guk hyŏndaesa 수정주의와 한국 현 대사 [(Cold War) Revisionism and Korean Contemporary History]. Sŏul 서울: Yŏnse taehakkyo ch'ulp'anbu 연세대학교출판부.

Yun, U 윤우. 2017. Taehan min'gug'ǔi kŏn'guksa'wa cheongt'ongsŏng: “1919nyŏn kŏn'guk1948nyŏn chaegŏn" "ŭn hŏnbŏp kyuchŏng ida 대한민국의 건국사와 정통성 “1919 년 건국 1948 재건" 은 헌법 규정이다 [The Founding History of South Korea and Legitimacy: "1919 
Foundation - 1948 Re-Establishment" is the Definition in the Constitution]. Soul 서울: Paeksansŏdang 백산서당.

$\begin{array}{ll}\text { ABBREVIATIONS } & \\ \text { DPRK } & \text { Democractic People's Republic of Korea } \\ \text { LF } & \text { Liberalist Federation } \\ \text { MCST } & \text { Ministry of Culture, Sports, and Tourism } \\ \text { NRF } & \text { New Right Foundation } \\ \text { NNRA } & \text { National New Right Association } \\ \text { NSL } & \text { National Security Law } \\ \text { TF } & \text { Textbook Forum } \\ \text { UN } & \text { United Nations } \\ \text { US } & \text { United States of America } \\ \text { WW2 } & \text { Second World War }\end{array}$

\section{GLOSSARY}

386 sedae

chaegŏn

chahak sagwan

Chayujuŭi Yŏndae

chehŏn hŏnbop

chehŏnjŏl

chinbo

chinbukchwap'a

ch'inilp'a

(nambuk) chŏngbu

surip

chŏngdangsong

chŏnhyangja

chŏngt'ongsŏng

chusap'a

ch'usu

Colonial Modernity

Theory

dai-ichiji kenkokusetsu 第一次建国節論争 ronsō

386 세대 (386 世代)
재건 (再建)
자학사관 (自虐史観)
자유주의연대
(自由主義連帶)
제헌헌법 (制憲憲法)
제헌절 (制憲節)
진보 (進歩)
진북좌파 (親北左派)
친일파 (親日派)
(남북) 정부수립
(南北)政府樹立
정당성 (正当性)
전향자 (転向者)
정통성 (正統性)
주사파 (主思派)

추수 (秋収)

식민지근대화론

(植民地近代化論)
386 Generation

Rebuilding, Reconstruction

"A masochistic view of history"

Liberalist Foundation

Founding Constitution of South Korea

Day of the Constitution. Public holiday, July 17

Progressive

(Pro-Japanese) Collaborator

Promulgation of two separate governments in North and South Korea in 1948

Legitimacy

A Convert

Legitimacy, "orthodoxy"

An ideological stream of the 1980s student democratisation movement studying the Juche Ideology Abbreviation of chuch'e sasang-p'a (주체사상파 / 主體思想派)

Autumn harvest

An academic theory arguing that the roots of modernity in Korea lie in colonial development. Proposed by scholars of the New Right, most notably An Pyŏng-jik and Yi Yŏng-hun First Kŏn'gukchŏl Dispute. Term used in Japanese to refer to the 2008 Kŏn'gukchŏl 


$\begin{array}{ll}\text { Dokdo / Takeshima } & \text { 독도 (独島) / 竹島 } \\ \text { Hannara-dang } & \text { 한나라당 } \\ \text { haebang } & \text { 해방 (解放) } \\ \text { hyŏndaesa } & \text { 현 대사 (現代史) } \\ \text { inmin chŏnggwŏn } & \text { 인민정권 창건일 } \\ \text { ch'anggónil } & \text { (人民政權 創建日) } \\ \text { Insadong } & \text { 인사동 (仁寺洞) } \\ \text { kaech'ǒnjŏl } & \text { 개천절 (開天節) } \\ \text { Kim Ku } & \text { 김구 (金九) } \\ \text { Kim Kyu-sik } & \text { 김규식 (金奎植) } \\ \text { kŏn'guk } & \text { 건국 (建國) } \\ \text { kŏn'guk hunjang } & \text { 건국훈장 (建國勳章) } \\ \text { kŏn'gukchŏl } & \text { 건국절 (建國節) } \\ \text { kŏn'guksa } & \text { 건국사 (建國史) } \\ \text { kŏn'guk sagwan } & \text { 건국사관 (建國史觀) } \\ \text { kŏn'guk 60-nyŏn } & \text { 건국 60 년 (建國 60 } \\ & \text { 年) }\end{array}$

kŏn'guk 60-chunyŏn
Kŏn'guk 60-nyŏn
Kinyŏm Haksul
Hoewoe
Kŏn'guk 60-nyŏn
Kinyŏm Saop Chunbi
Wiwŏnhoe

Kukhoebo

kukka poanbŏp

kukkyŏng'il

kwangbok

Kwangbokhoe

kwangbokchŏl

Kwanghwamun

Kyogwasŏ P'orŏm

건국 60 주년 (建國 60 周年) 의

(建國 60 年記念學術

會議)

건국 60 년기념사업준

비위원회

(建國 60 年記念事業

準備委員會)

國会報

法)

국경일 (國慶日)

광복 (光復)

광복회 (光復會)

광복절 (光復節)

광화문 (光化門)
Dispute

Two islands whose territoriality is heavily disputed between Japan and South Korea Hannara Party (also: Grand National Party) Name of the major conservative political party from 1997 to 2012

Liberation

Contemporary history

Public holiday in North Korea, September 9

An area in central Seoul

Public Holiday, mythical foundation of ancient Korea, October 3

Independence activist and right-wing politician (1876-1949)

Independence activist and right-wing politician (1881-1950)

Literally, "foundation of the state/nation"

Order of Merit for National Foundation

Proposed name for August 15 as opposed to kwangbokchŏl

History of the South Korean state formation

Kŏn'guk view

Term used in 2008 commemoration events to refer to 60 years of South Korean history as "60 years of foundation"

건국 60 년기념학술회 A symposium held by New Right scholars in 2007 to elaborate on South Korean history from the kŏn'guk view

A monthly journal

국가보안법 (國家保安 National Security Law (NSL)

Preparation Committee for Commemorative Events of the 60th Anniversary of the Foundation

The highest national holiday in South Korea "return of the light"

A civic organisation consisting of independence activists and their decedents

Public holiday, August 15

The largest gate to Kyŏngbokgung palace, the major palace of the five royal palaces of Seoul Textbook Forum 


\begin{tabular}{|c|c|c|}
\hline & 포럼) & \\
\hline Kyŏngbokgung & 경복궁 (景福宮) & $\begin{array}{l}\text { One of the five royal palaces of the Chosonn } \\
\text { Dynasty in Seoul }\end{array}$ \\
\hline minjung & 민중 & "the mass," "the people" \\
\hline $\begin{array}{l}\text { Munhwa Ch'eyuk } \\
\text { Kwan'gwangbu }\end{array}$ & $\begin{array}{l}\text { 문화체육관광부 } \\
\text { (文化體育觀光部) }\end{array}$ & Ministry of Culture, Sports, and Tourism \\
\hline nara & 나라 & Country, state, nation \\
\hline Nyurait'ŭ Chaedan & $\begin{array}{l}\text { 뉴라이트 재단 } \\
\text { (뉴라이트財団) }\end{array}$ & New Right Foundation \\
\hline $\begin{array}{l}\text { Nyurait'ŭ Chŏn'guk } \\
\text { Yönhap }\end{array}$ & $\begin{array}{l}\text { 뉴라이트전국연합 } \\
\text { (뉴라이트소或連合) }\end{array}$ & National New Right Association \\
\hline Nyurait' 'ŭ Net' 'ǔwŏk' $\breve{u}$ & 뉴라이트 네트워크 & New Right Network \\
\hline posu & 보수 (保守) & Conservative \\
\hline pundan & 분단 (分断) & Separation, division \\
\hline Sidae Chŏngsin & 시대정신 (時代精神) & $\begin{array}{l}\text { Zeitgeist. Journal published by the New Right } \\
\text { from 2006-2017 }\end{array}$ \\
\hline sam'ilchŏl & 삼일절 (三一節) & Public holiday. March 1 \\
\hline sŏnjinhwa & 선진화 (先進化) & Advancing \\
\hline sŏn'gong'ǔi yŏksa & $\begin{array}{l}\text { 선공의 역사 (成功의 } \\
\text { 歴史) }\end{array}$ & History of Success \\
\hline Yi Süng-man & 이승만 (李承晚) & $\begin{array}{l}\text { Syngman Rhee (1875-1960); Independence } \\
\text { activist, first president of South Korea (1948- } \\
1960)\end{array}$ \\
\hline tanbi & 단비 (甘雨) & spring rain \\
\hline Tan'gun & 단군 (檀君) & The Mythical founder of Korea \\
\hline Taehan min'guk & 대한민국 (大韓民國) & Official name of South Korea \\
\hline Taehan Min'guk & 대한민국건국 60 년기 & Committee for Commemorative Events of the \\
\hline Kŏn'guk 60-nyŏn & 념사업위원회 (大韓民 & 60th Anniversary of the Foundation of South \\
\hline $\begin{array}{l}\text { Kinyŏm Să̌p Wiwŏn- } \\
\text { hoe }\end{array}$ & $\begin{array}{l}\text { 國建國 } 60 \text { 年記念事業 } \\
\text { 委員會) }\end{array}$ & Korea \\
\hline T'apgol kongwŏn & 탑골공원 (塔谷公園) & A park located near Insadong in central Seoul \\
\hline tongnip & 독립 (独立) & Independence \\
\hline Tsukuru-kai & つくる会 & $\begin{array}{l}\text { A civic organisation founded in } 1996 \text { to re- } \\
\text { narrate Japanese history. Claiming Japanese } \\
\text { textbooks to present a "masochistic view of } \\
\text { history," Tsukuru-kai is a central organisation } \\
\text { in Japanese right-wing historical revisionism }\end{array}$ \\
\hline Yŏllin Uri-dang & 열린우리당 & $\begin{array}{l}\text { The Uri Party, a progressive party founded in } \\
2003 \text {, dissolved in } 2007\end{array}$ \\
\hline Yŏksa Munje Yŏnguso & $\begin{array}{l}\text { 역사문제연구소 (歴史 } \\
\text { 問題研究所) }\end{array}$ & $\begin{array}{l}\text { A research institute dedicated to Korean } \\
\text { contemporary history }\end{array}$ \\
\hline Yŏksa Munje Yŏngu & $\begin{array}{l}\text { 역사문제연구 (歴史問 } \\
\text { 題研究) }\end{array}$ & An academic journal \\
\hline Yǒksa Pip’yŏng & 역사비평 (歴史批評) & An academic journal \\
\hline Yusin & 유신 (維新) & $\begin{array}{l}\text { Literally, "restauration." The highly authori- } \\
\text { tarian Fourth Republic of Korea (1972-1980) }\end{array}$ \\
\hline
\end{tabular}

